\title{
The 1994 Northridge earthquake sequence in California: Seismological and tectonic aspects
}

\author{
Egill Hauksson \\ Seismological Laboratory, Division of Geological and Planetary Sciences, California Institute of Technology, Pasadena
}

Lucile M. Jones

U. S. Geological Survey, Pasadena, Califomia

Kate Hutton

Seismological Laboratory, Division of Geological and Planetary Sciences, California Institute of Technology, Pasadena

Abstract. The $M_{w} 6.7$ Northridge earthquake occurred on January 17, 1994, beneath the San Fernando Valley. Two seismicity clusters, located $25 \mathrm{~km}$ to the south and $35 \mathrm{~km}$ to the north-northwest, preceded the mainshock by 7 days and 16 hours, respectively. The mainshock hypocenter was relatively deep, at $19 \mathrm{~km}$ depth in the lower crust. It had a thrust faulting focal mechanism with a rake of $100^{\circ}$ on a fault plane dipping $35^{\circ}$ to the south-southwest and striking $N 75^{\circ} \mathrm{W}$. Because the mainshock did not npture the surface, its association with surficial geological features remains difficult to resolve. Nonetheless, its occurrence reemphasized the seismic hazard of concealed faults associated with the contractional deformation of the Transverse Ranges. The Northridge earthquake is part of the temporal increase in earthquake activity in the Los Angeles area since 1970. The mainshock was followed by an energetic aftershock sequence. Eight aftershocks of $M \geq 5.0$ and 48 aftershocks of $4 \leq M<5$ occurred between January 17 and September 30, 1994. The aftershocks extend over most of the western San Femando Valley and Santa Susana Mountains. They form a diffuse spatial distribution around the mainshock rupture plane, illuminating a previously unmapped thrust ramp, extending from $7-10 \mathrm{~km}$ depth into the lower crust to a depth of $23 \mathrm{~km}$. No flattening of the aftershock distribution is observed near its bottom. At shallow depths, above 7-10 km, the thrust ramp is topped by a dense distribution of aftershock hypocenters bounded by some of the surficial faults. The dip of the ramp increases from east to west. The west side of the aftershock zone is characterized by a dense, steeply dipping, and north-northeast striking planar cluster of aftershocks that exhibited mostly thrust faulting. These events coincided with the Gillibrand Canyon lateral ramp. Along the east side of the aftershock zone the aftershocks also exhibited primarily thrust faulting focal mechanisms. The focal mechanisms of the aftershocks were dominated by thrust faulting in the large aftershocks, with some strike-slip and normal faulting in the smaller aftershocks. The 1971 San Femando and the 1994 Northridge earthquakes ruptured partially abutting fault surfaces on opposite sides of a ridge. Both earthquakes accommodated north-south contractional deformation of the Transverse Ranges. The two earthquakes differ primarily in the dip direction of the faults and the depth of faulting. The 1971 northnortheast trend of left-lateral faulting (Chatsworth trend) was not activated in 1994.

\section{Introduction .}

The $1994 M_{w} 6.7$ Northridge earthquake is the latest in a series of moderate-sized to large earthquakes to occur in the north Los Angeles region [Hauksson, 1992]. The earthquake occurred on a south-southwest dipping thrust ramp located to the southwest of the west end of the Sierra Madre fault system and to the south of the east end of the Santa Susana, San Cayetano, and Oak Ridge fault systems (Figure 1) [Proctor et al., 1972; Yeats, 1981; Çemen, 1989]. The occurrence of the earthquake away from

Copyright 1995 by the American Geophysical Union.

Paper number 95JB00865.

0148-0227/95/95JB-00865 $\$ 05.00$ mapped surface fault structures demonstrated the complex threedimensional nature of the tectonics in this region. Like all of the significant earthquakes that have occurred since the 1920 s in southem California, the Northricge earthquake thus provided new insights into the regional tectonics and seismological aspects of such sequences.

Since 1920,15 moderate-sized to large ( $M$ 4.8-6.7) mainshockaftershock sequences have occurred in the greater Los Angeles area (Figure 1). These earthquakes are associated with many low slip-rate, late Quatemary faults distributed throughout the region. Because surface rupture has only occurred once since the 1920s, during the 1971 San Fernando earthquake, the association between a mainshock hypocenter and a nearby fault typically has been inferred from the mainshock focal mechanism and the distribution of aftershocks. They have been associated with surficial reverse faults, right-lateral or left-lateral strike-slip 

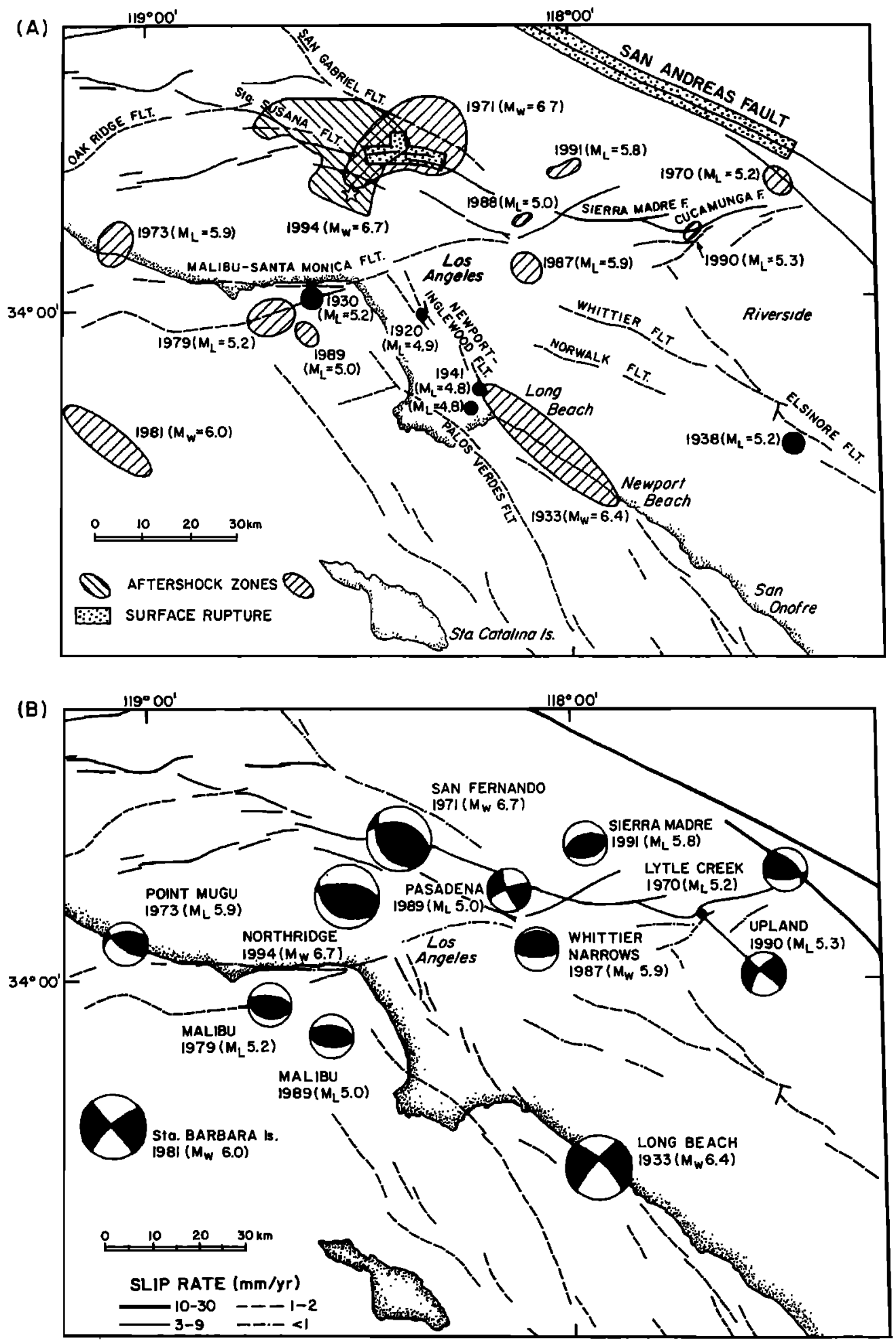

Figure 1. (a) Significant earthquakes of $M \geq 4.8$ that have occurred in the greater Los Angeles basin area since 1920. Aftershock zones are shaded with cross hatching, including the 1994 Northridge earthquake. Dotted areas indicate surface rupture, including the rupture of the 1857 earthquake along the San Andreas fault. (b) Lowerhemisphere focal mechanisms (shaded quadrants are compressional) for significant earthquakes that have occurred since 1933 in the greater Los Angeles area.

faults, and concealed thrust ramps [Hauksson, 1990], reflecting the merging of the strike-slip deformation of the Peninsular Ranges with the contractional deformation of the Transverse Ranges.
The rate of tectonic deformation across the northern Los Angeles area and the central Transverse Ranges is relatively high [Donnellan et al., 1993; Hudnut et al., 1995]. Global Positioning System measurements across the Ventura basin, $30 \mathrm{~km}$ northwest 
of the Northridge rupture, show north-south shortening of 7-10 $\mathrm{mm} / \mathrm{yr}$, that may be accommodated by the San Cayetano, Red Mountain, and Oak Ridge faults [Donnellan et al., 1993]. Similar measurements across the Los Angeles basin indicate shortening rates of 5-10 mm/yr [Feigl et al., 1993].
The long-term (1978 to 1993) background seismicity in the central Transverse Ranges is dominated by aftershocks of the $1971 M_{W} 6.7$ San Fernando earthquake (Figure 2). A few of the large clusters in the north Los Angeles region are also earlier mainshock-aftershock sequences [Hauksson, 1990]. To the south

(A)

Seismicity $1978-1993$

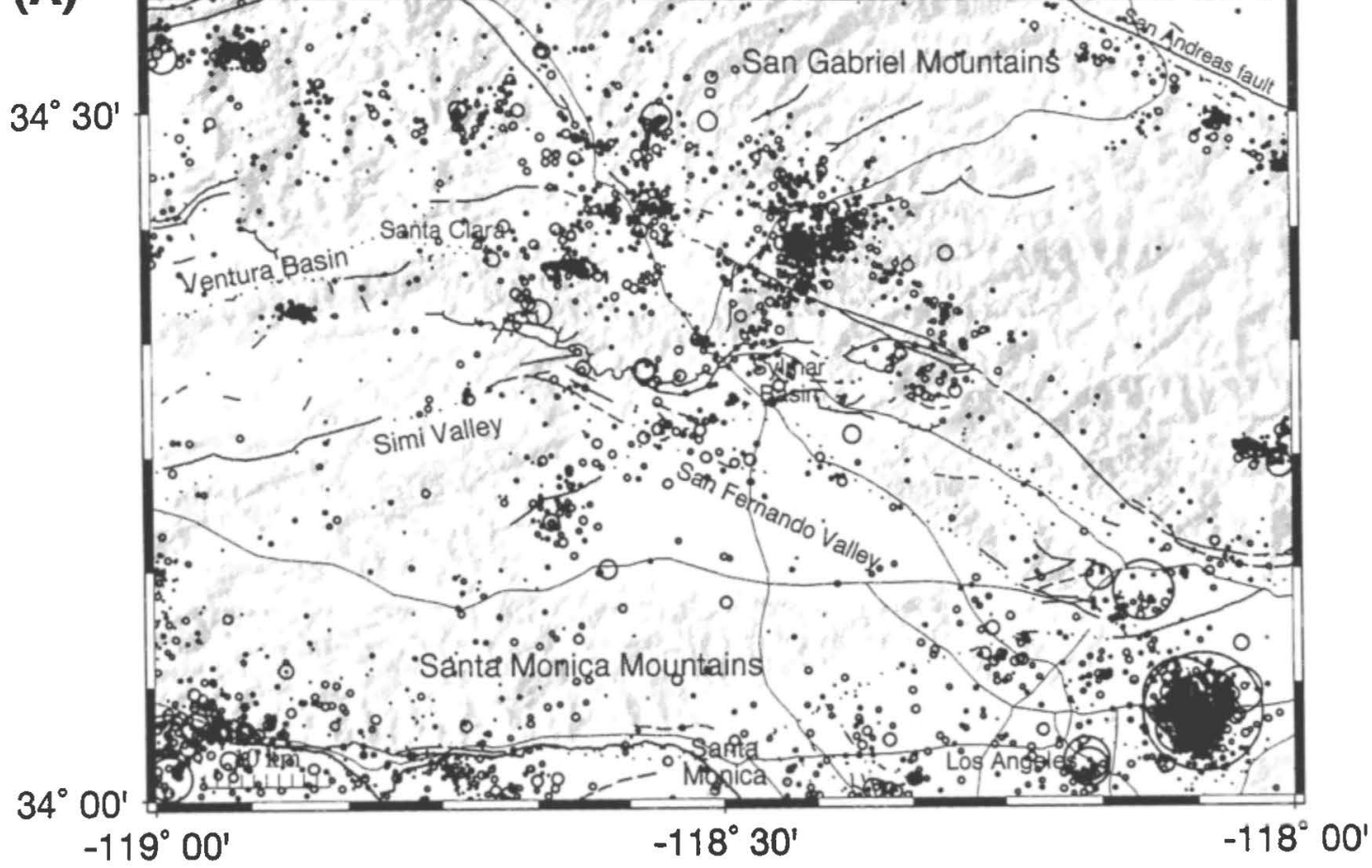

(B)

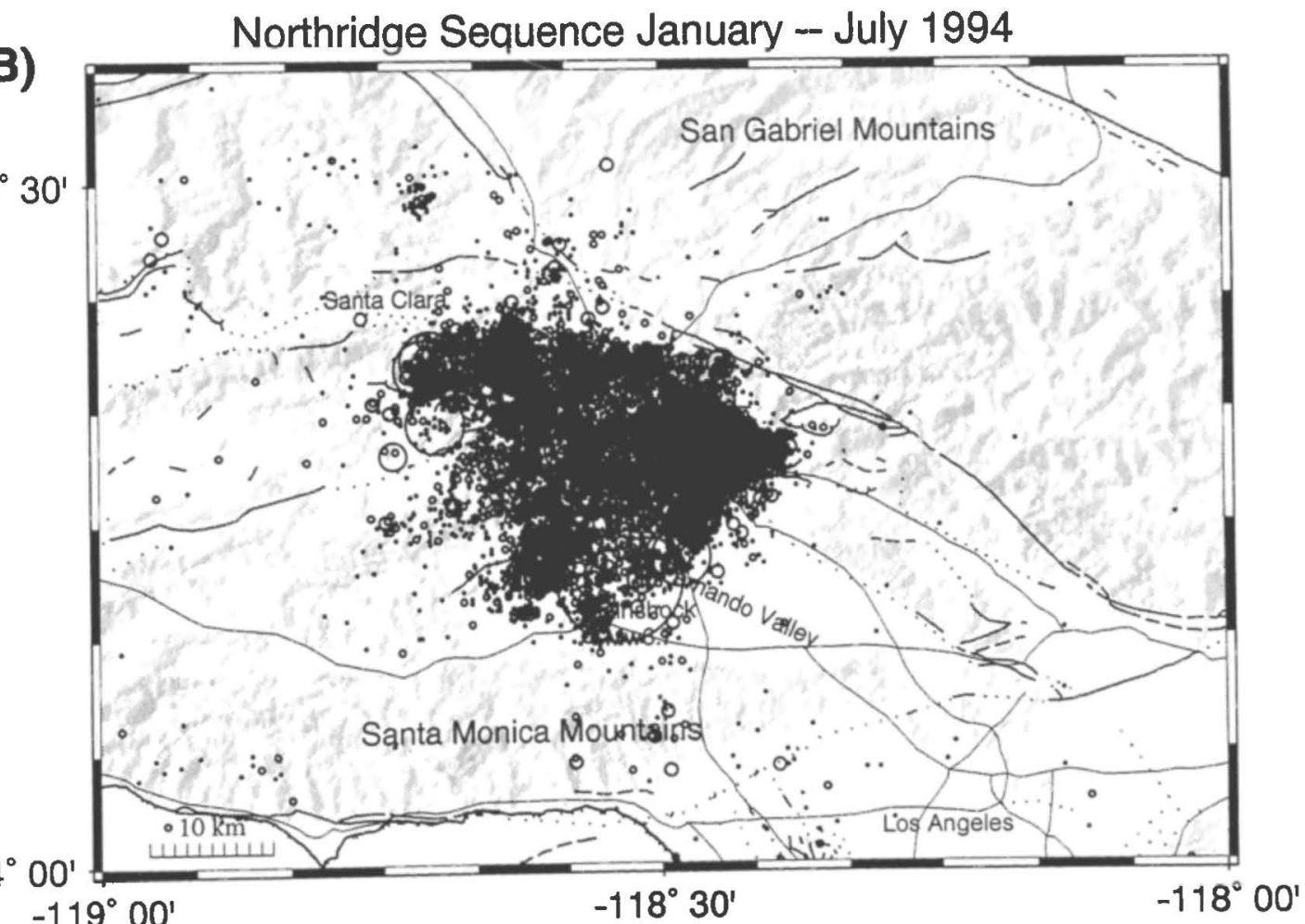

Figure 2. (a) Map of background seismicity in the San Fernando region from 1978 to 1993. (b) Map of Northridge mainshock, aftershocks, and background seismicity in the same region from January 17 to July 1994. (Plotted with GMT software, Wessel and Smith, 1991). 
of the 1971 aftershock zone, the seismicity in the San Fernando Valley region has been characterized by a low-level background seismic activity that did not illuminate individual or distinctive fault structures beneath the valley. Both to the north and south of the valley, tectonic models of north dipping surficial reverse faults or concealed north dipping thrust ramps were supported primarily by geologic data and in a few cases by the background seismicity [Namson and Davis, 1992; Hauksson, 1990]. In comparison, the 1994 Northridge sequence extended across a wide area and provided new data for the valley and the eastern part of the Santa Susana Mountains (Figure 2b). Both the west and east edges of the 1994 aftershock zone form distinct northnortheast trends and appear to coincide with some of the similar trends ir the background seismicity. Future analysis of the background seismicity thus may contribute to understanding of possible segmentation of concealed faults.

The two largest earthquakes to occur in this region during this century are the 1971 San Fernando and the 1994 Northridge earthquakes (Figure 1). Although the Northridge earthquake was the same size as the 1971 San Fernando earthquake $\left(M_{w} 6.7\right)$, it was much more damaging, in part because of its location beneath the heavily populated San Fernando Valley and its proximity to other communities in the Los Angeles basin. In map view the aftershock zones of both earthquakes overlap, suggesting that the causative thrust faults are at least geometrically related.

The 1994 Northridge earthquake and its aftershocks illuminate for the first time a south dipping thrust ramp beneath the San
Fernando Valley, which serves to emphasize the hazard associated with undetected thrust faults in this region. In this paper we synthesize the seismological observations from the Northridge earthquake sequence to facilitate our understanding of the role these tectonic structures play in the regional crustal deformation of the compressional zone of the central Transverse Ranges. The long range goal of these studies is to provide comprehensive understanding of tectonic deformation associated with the big bend region of the San Andreas fault system in southern California.

\section{Data and Procedures}

We analyzed the $P$ and $S$ wave arrival times and $P$ wave first motions from the Southem California Seismic Network (SCSN), operated by the U.S. Geological Survey and the California Institute of Technology (USGS/CIT), to obtain high-quality hypocenters and focal mechanisms. To date, the SCSN has recorded approximately 10,000 Northridge aftershocks.

Arrival time data from 300 earthquakes were simultaneously inverted for improved hypocenters, a one-dimensional velocity model, and a set of station delays using the VELEST code [Kissling et al., 1994]. Arrival time data were used from the stations shown in Figure 3. The starting and final velocity models are listed in Table 1. The resultant models and delays were used as input to HYPOINVERSE [Klein, 1985] to obtain final locations for both sequences, which included more than 10,000

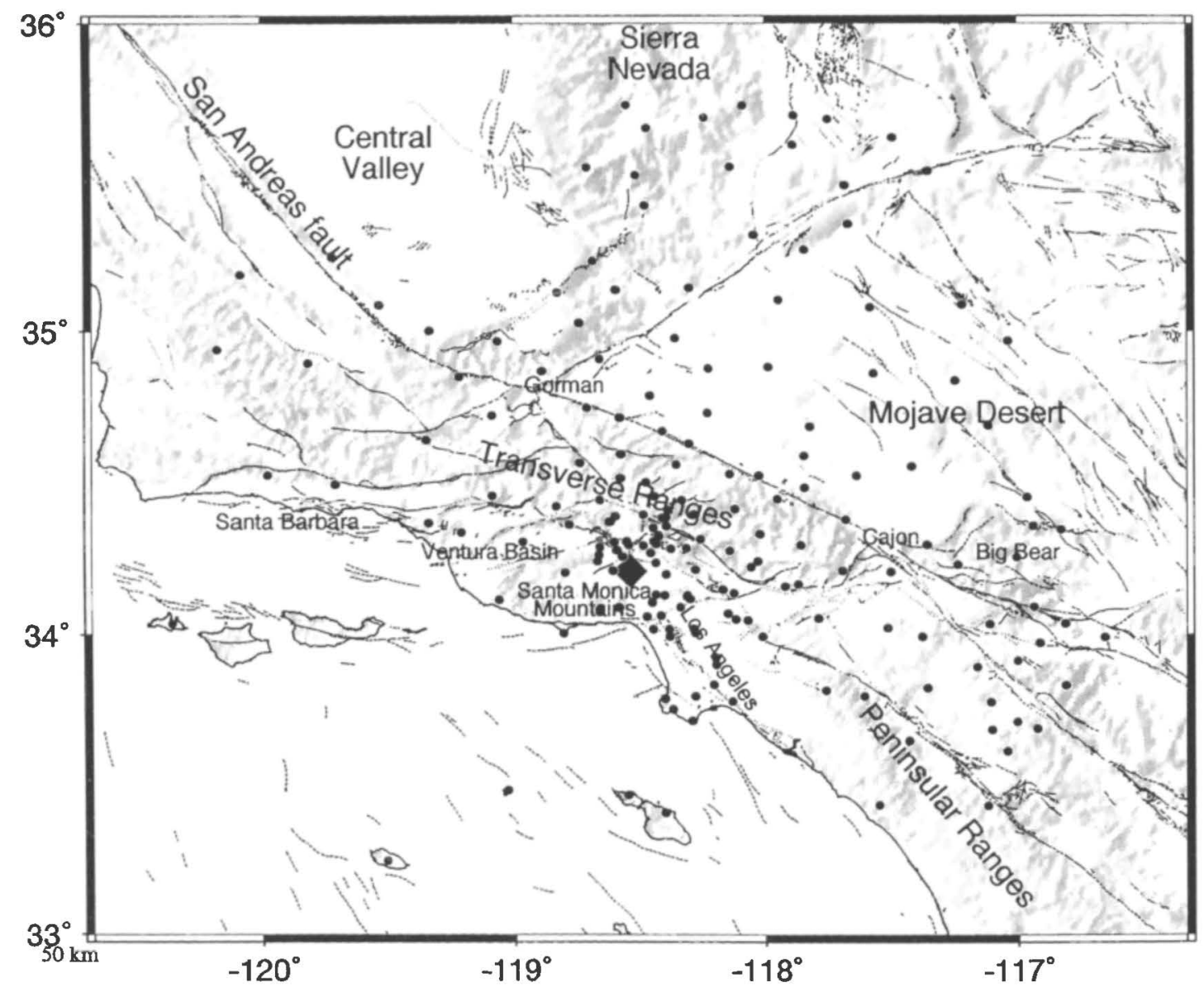

Figure 3. Map of the Southern California Seismographic Network (SCSN) showing seismic stations used to relocate the Northridge earthquakes. Seismic stations are shown by solid circles. The $M_{w} 6.7$ Northridge mainshock is shown as a diamond. 
Table 1. $P$ Wave Velocity Models

\begin{tabular}{lll}
\hline $\begin{array}{l}\text { Initial } \\
\text { Velocity, } \\
\mathrm{km} / \mathrm{s}\end{array}$ & $\begin{array}{l}\text { Refined } \\
\text { Velocity, } \\
\mathbf{k m} / \mathrm{s}\end{array}$ & $\begin{array}{l}\text { Depth to Top } \\
\text { of Layer, } \\
\mathbf{k m}\end{array}$ \\
\hline 5.20 & 4.80 & 0.00 \\
5.70 & 5.78 & 4.00 \\
6.10 & 6.15 & 6.00 \\
6.30 & 6.30 & 8.00 \\
6.40 & 6.44 & 12.0 \\
6.70 & 6.54 & 16.0 \\
6.90 & 6.72 & 20.0 \\
7.80 & 7.76 & 32.0 \\
\hline
\end{tabular}

events in 1994 and 1100 events in 1971-1972. The relative vertical and horizontal uncertainties in the hypocenters are in most cases less than $1 \mathrm{~km}$. The final locations on the average had a root-mean-square residual (rms) of $0.10 \mathrm{~s}$ as compared with the ms of $0.25 \mathrm{~s}$ when using the starting model.

More than 4500 single-event, lower-hemisphere focal mechanisms were determined using the grid-searching algorithm and computer programs by Reasenberg and Oppenheimer [1985]. The average uncertainties in the dip direction (which is equal to strike plus $90^{\circ}$ ), dip, and rake of the focal mechanisms for the whole data set are $12^{\circ}, 14^{\circ}$, and $20^{\circ}$, respectively. To provide an overview of the sequence only a few typical focal mechanisms for the large events are shown in the figures. Focal mechanisms with first-motion polarities for $M \geq 4$ events are shown in Figure 4 and listed in Table 2. If two focal mechanisms fit the first-motion data from an event about equally well, both are shown in Figure 4. In subsequent figures the first mechanism is selected for plotting.

\section{Results}

\section{Precursory Seismicity Clusters?}

The epicentral area of the Northridge earthquake remained seismically inactive during the preceding month. Two different clusters of small earthquakes occurred at distances of $25-35 \mathrm{~km}$ during the preceding month (Figure 5). The first occurred under Santa Monica Bay adjacent to the coastline. The second occurred in Santa Clarita Valley, $4 \mathrm{~km}$ north of the surface trace of the Holser fault. Both the spatial and temporal relationships to the subsequent Northridge mainshock suggest but do not require a causative relationship.

The Santa Monica swarm during the week before January 17, 1994, was located $25 \mathrm{~km}$ due south of the mainshock epicenter. The swarm started with an $M 3.7$ mainshock on January 9 at 2300 UT. This shock was felt in west Los Angeles although it caused no significant damage. During the next 7 days a total of 15 events of $M \geq 1.5$ were recorded with the largest aftershock being a $M 3.5$ on January 12 (1928 UT). This sequence is referred to as a swarm because the two largest events were of similar size, and because the rate of earthquake activity stayed about the same for 2 or 3 days, rather than decaying with time as aftershocks normally do.

The Santa Monica swarm formed a tight cluster of less than 1 $\mathrm{km}$ radius in the depth range of 3-12 $\mathrm{km}$. This depth distribution is significantly shallower than the depth of the Northridge sequence (Figure 5c). The locations and focal mechanisms of these 15 events show that this swarm occurred on a previously unmapped offshore reverse fault, with a nearly east-west strike and possibly a steep dip to the south. This sequence is a part of the north-south contractional deformation of the Transverse Ranges. The last event in the Santa Monica swarm occurred about 18 hours before the Northridge mainshock.

During the 16 hours preceding the mainshock, a small cluster of four earthquakes of $M$ 1.3-1.9 occurred at $15 \mathrm{~km}$ depth, located $35 \mathrm{~km}$ north-northwest of the future mainshock epicenter. The largest of these events had a thrust focal mechanism with one east striking nodal plane dipping gently to the north. Because these events are of small magnitude and occurred at depths of $15 \mathrm{~km}$, it is not possible to assign them to surficial faults. These events, tightly clustered within a volume of $1 \mathrm{~km}^{3}$, and the focal mechanisms are consistent with the ongoing contractional deformation of the Transverse Ranges (Figure 5).

Both the Santa Monica and the Holser swarm are unusual in terms of the background activity recorded in the region since 1930 by the SCSN, and their relationship to the Northridge mainshock is not understood. Swarms like the Santa Monica swarm are fairly rare along the Santa Monica coastline, although they are common further offshore in Santa Monica Bay [Hauksson and Saldivar, 1989]. Small clusters like the Holser swarrn, however, have occurred in this region in the past (Figure 2). Because both clusters occurred on different faults and more than one fault dimension away from the subsequent Northridge mainshock, we do not consider either cluster to be a precursor or a foreshock sequence to the Northridge mainshock, as defined by Jones [1984].

\section{Focal Mechanisms of the Mainshock and $M \geq 4$ Aftershocks}

The first-motion focal mechanism of the mainshock exhibited one nodal plane striking $105^{\circ} \pm 10^{\circ}$ and dipping $35^{\circ} \pm 5^{\circ}$ southsouthwest with a rake of $100^{\circ} \pm 10^{\circ}$. Other determinations of the mainshock focal mechanism based on teleseismic and regional broadband waveforms show a more northerly strike of N50-60\% and a somewhat steeper dip of $40^{\circ}-45^{\circ}$ to the south-southwest [Dreger, 1994; Thio and Kanamori, 1995]. This difference in the mainshock focal mechanism determined with different frequency waves suggests a small increase in dip along strike and possibly a curved rupture surface. Such an increase in dip along strike can also be seen in the distribution of aftershocks.

Although no surface rupture has been found [Scientists of the U.S. Geological Survey and the Southern California Earthquake Center, 1994], hereinafter referred to as (USGS and SCEC, 1994), several preliminary interpretations of the mainshock faulting have been offered. One interpretation suggests that the Oak Ridge fault, mapped to the west in the Ventura basin, extends into this region [Yeats and Huftile, 1994]. Another interpretation could be that some of the surficial faults exposed farther north, such as the Holser fault, are responsible for the earthquake. A third interpretation models the earthquake as slip on a south-dipping thrust ramp beneath the San Femando Valley [Davis and Namson, 1994]. The seismological evidence for the mainshock faulting, the focal mechanism and the spatial distribution of aftershocks, are consistent with all three interpretations.

The large aftershocks occurred both to the north and south of the surface trace of the east-west striking, north dipping Santa Susana thrust fault, the most prominent surficial reverse fault in the region (Figure 5). Although it did not rupture in the mainshock, it appears to influence the spatial distribution of 


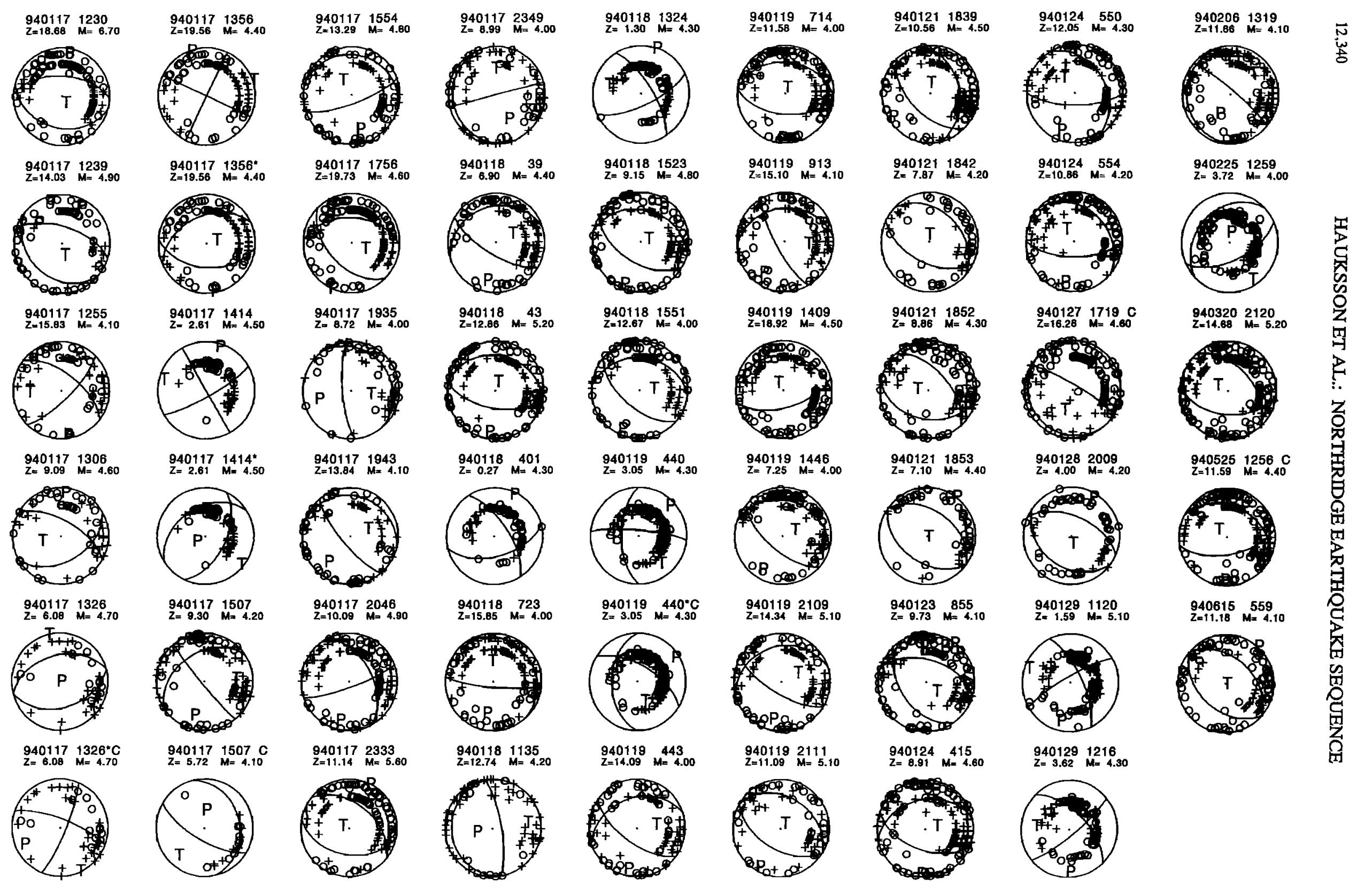

Figure 4. Single-event, first motion lower-hemisphere focal mechanisms of $M \geq 4.0$ events. Compressional first motions are shown by pluses and dilational first motions are shown by open circles. Alternate focal mechanisms are flagged by an asterisk. 
Table 2. Locations and Focal Mechanisms of Earthquakes in the 1994 Northridge Sequence

\begin{tabular}{|c|c|c|c|c|c|c|c|c|c|}
\hline $\begin{array}{l}\text { Origin } \\
\text { Date }\end{array}$ & $\begin{array}{c}\text { Time, } \\
\text { UT }\end{array}$ & $\begin{array}{c}\text { Latitude } \\
\mathbf{N}\end{array}$ & $\begin{array}{c}\text { Longitude } \\
\text { W }\end{array}$ & $\begin{array}{c}\text { Depth, } \\
\mathbf{k m}\end{array}$ & $\begin{array}{c}\text { Magnitude } \\
M \\
\end{array}$ & $\frac{\text { Focal }}{\text { Dedir }}$ & Mech & $\frac{\text { aisms, deg }}{\text { Rake }}$ & $\begin{array}{l}\text { Number of } \\
\text { Eirst Motions }\end{array}$ \\
\hline Jan. 17, 1994 & 1230 & $34^{\circ} 12.55^{\circ}$ & $118^{\circ} 32.44^{\prime}$ & 18.7 & 6.7 & 195 & 35 & 100 & 135 \\
\hline Jan. 17, 1994 & 1231 & $34^{\circ} 15.49^{\prime}$ & $118^{\circ} 28.41^{\prime}$ & 5.4 & 5.9 & & & & \\
\hline 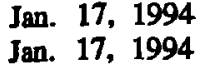 & $\begin{array}{l}1234 \\
1239\end{array}$ & $\begin{array}{l}34^{\circ} 16.49^{\prime} \\
34^{\circ} 1520^{\prime}\end{array}$ & $118^{\circ} 28.10^{\prime}$ & $\begin{array}{r}8.5 \\
14.0\end{array}$ & 4.4 & & & & \\
\hline $\begin{array}{ll}\text { Jan. } 17,1994 \\
\text { Jan. } 17,1994\end{array}$ & $\begin{array}{l}1239 \\
1240\end{array}$ & $\begin{array}{l}34^{\circ} 15.20^{\prime} \\
34^{\circ} 18.36^{\prime}\end{array}$ & $\begin{array}{l}118^{\circ} 32.29^{\prime} \\
118^{\circ} 30.30^{\prime}\end{array}$ & $\begin{array}{r}14.0 \\
5.7\end{array}$ & 4.9 & 220 & 30 & 110 & 71 \\
\hline $\begin{array}{l}\text { Jan. } 17,1994 \\
\text { Jan. } 17,1994\end{array}$ & 1240 & $34^{\circ} 19.95^{\prime}$ & $118^{\circ} 35.41^{\prime}$ & 1.7 & $\begin{array}{l}4.8 \\
5.2\end{array}$ & & & & \\
\hline Jan. 17, 1994 & 1254 & $34^{\circ} 18.22^{\prime}$ & $118^{\circ} 27.85^{\prime}$ & 4.2 & 4.0 & & & & \\
\hline Jan. 17, 1994 & 1255 & $34^{\circ} 15.82$ & $118^{\circ} 34.97$ & 15.8 & 4.1 & 135 & 75 & 30 & 66 \\
\hline Jan. 17, 1994 & 1306 & $34^{\circ} 15.03^{\circ}$ & $118^{\circ} 32.95^{\prime}$ & 9.1 & 4.6 & 150 & 45 & 40 & 59 \\
\hline Jan. 17, 1994 & 1326 & $34^{\circ} 18.80^{\prime}$ & $118^{\circ} 27.00^{\prime}$ & 6.1 & 4.7 & 165 & 45 & -90 & 45 \\
\hline Jan. 17, 1994 & 1328 & $34^{\circ} 16.14^{\prime}$ & $118^{\circ} 34.56^{\prime}$ & 0.4 & 4.0 & & & & \\
\hline Jan. 17, 1994 & 1356 & $34^{\circ} 17.04^{\prime}$ & $118^{\circ} 37.53^{\prime}$ & 19.6 & 4.4 & 115 & 90 & 0 & 91 \\
\hline Jan. 17, 1994 & 1414 & $34^{\circ} 19.11^{\prime}$ & $118^{\circ} 27.04^{\prime}$ & 2.6 & 4.5 & 60 & 90 & 170 & 60 \\
\hline Jan. 17, 1994 & 0157 & $34^{\circ} 17.83^{\prime}$ & $118^{\circ} 28.65^{\prime}$ & 9.3 & 4.2 & 230 & 85 & 130 & 97 \\
\hline Jan. 17, 1994 & 0157 & $34^{\circ} 17.83^{\prime}$ & $118^{\circ} 28.36^{\prime}$ & 5.7 & 4.1 & 210 & 70 & -110 & 18 \\
\hline Jan. 17, 1994 & 1554 & $34^{\circ} 22.17^{\prime}$ & $118^{\circ} 37.86^{\prime}$ & 13.3 & 4.8 & 160 & 75 & 80 & 103 \\
\hline Jan. 17, 1994 & 1756 & $34^{\circ} 13.31^{\prime}$ & $118^{\circ} 34.44^{\prime}$ & 19.7 & 4.6 & 225 & 50 & 120 & 130 \\
\hline Jan. 17, 1994 & 1935 & $34^{\circ} 18.27^{\prime}$ & $118^{\circ} 27.90^{\prime}$ & 8.7 & 4.0 & 26 & 75 & 100 & 51 \\
\hline Jan. 17, 1994 & 1943 & $34^{\circ} 21.87^{\prime}$ & $118^{\circ} 38.56^{\prime}$ & 13.8 & 4.1 & 230 & 75 & 100 & 78 \\
\hline Jan. 17, 1994 & 2046 & $34^{\circ} 17.82^{\prime}$ & $118^{\circ} 34.25^{\prime}$ & 10.1 & 4.9 & 160 & 80 & 40 & 129 \\
\hline Jan. 17, 1994 & 2333 & $34^{\circ} 19.42^{\prime}$ & $118^{\circ} 42.18^{\prime}$ & 11.1 & 5.6 & 190 & 45 & 70 & 115 \\
\hline Jan. 17, 1994 & 2349 & $34^{\circ} 20.29^{\prime}$ & $118^{\circ} 40.18^{\prime}$ & - 9.0 & 4.0 & 165 & 90 & 100 & 82 \\
\hline Jan. 18, 1994 & 0039 & $34^{\circ} 22.42^{\prime}$ & $118^{\circ} 34.0^{\prime}$ & 6.9 & 4.4 & 210 & 70 & 110 & 90 \\
\hline Jan. 18, 1994 & 0040 & $34^{\circ} 23.05^{\prime}$ & $118^{\circ} 32.73^{\prime}$ & 4.5 & 4.2 & & & & \\
\hline Jan. 18, 1994 & 0043 & $34^{\circ} 22.22$ & $118^{\circ} 42.41^{\prime}$ & 12.9 & 5.2 & 190 & 60 & 90 & 132 \\
\hline Jan. 18, 1994 & 0041 & $34^{\circ} 20.83^{\prime}$ & $118^{\circ} 37.95^{\circ}$ & 0.3 & 4.3 & 165 & 55 & 30 & 68 \\
\hline Jan. 18, 1994 & 0723 & $34^{\circ} 19.58^{\prime}$ & $118^{\circ} 37.92^{\prime}$ & 15.8 & 4.0 & 185 & 80 & 80 & 117 \\
\hline Jan. 18, 1994 & 1135 & $34^{\circ} 12.72^{\prime}$ & $118^{\circ} 36.35^{\circ}$ & 12.7 & 4.2 & 8 & 75 & 90 & 70 \\
\hline Jan. 18, 1994 & 1324 & $34^{\circ} 18.48^{\prime}$ & $118^{\circ} 34.5^{\prime}$ & 1.3 & 4.3 & 155 & 70 & 20 & 84 \\
\hline Jan. 18, 1994 & 0152 & $34^{\circ} 22.36^{\prime}$ & $118^{\circ} 33.95^{\prime}$ & 9.1 & 4.8 & 210 & 55 & 100 & 119 \\
\hline Jan. 18, 1994 & 0551 & $34^{\circ} 14.54^{\prime}$ & $118^{\circ} 28.31^{\prime}$ & 12.7 & 4.0 & 220 & 60 & 110 & 97 \\
\hline Jan. 19,1994 & 0440 & $34^{\circ} 21.49^{\prime}$ & $118^{\circ} 34.14^{\prime}$ & 3.0 & 4.3 & 5 & 80 & 30 & 124 \\
\hline Jan. 19, 1994 & 0443 & $34^{\circ} 21.60^{\circ}$ & $118^{\circ} 42.62^{\prime}$ & 14.1 & 4.0 & 215 & 65 & 120 & 98 \\
\hline Jan. 19, 1994 & 0714 & $34^{\circ} 16.82^{\prime}$ & $118^{\circ} 28.44^{\prime}$ & 11.6 & 4.0 & 185 & 55 & 90 & 118 \\
\hline Jan. 19, 1994 & 0913 & $34^{\circ} 18.04^{\prime}$ & $118^{\circ} 44.45^{\circ}$ & 15.1 & 4.1 & 240 & 75 & 120 & 106 \\
\hline Jan. 19,1994 & 0014 & $34^{\circ} 12.52^{\prime}$ & $118^{\circ} 31.12^{\prime}$ & 18.9 & 4.5 & 65 & 60 & 80 & 122 \\
\hline Jan. 19,1994 & 1446 & $34^{\circ} 17.45^{\prime}$ & $118^{\circ} 27.83^{\prime}$ & 7.2 & 4.0 & 220 & 65 & 100 & 87 \\
\hline Jan. 19,1994 & 0219 & $34^{\circ} 21.81^{\prime}$ & $118^{\circ} 42.81^{\prime}$ & 14.3 & 5.1 & 210 & 70 & 110 & 124 \\
\hline Jan. 19,1994 & 2111 & $34^{\circ} 22.37^{\prime}$ & $118^{\circ} 37.16^{\prime}$ & 11.1 & 5.1 & 210 & 55 & 90 & 71 \\
\hline Jan. 21, 1994 & 1839 & $34^{\circ} 17.79^{\prime}$ & $118^{\circ} 28.14^{\prime}$ & 10.6 & 4.5 & 225 & 55 & 70 & 131 \\
\hline Jan. 21, 1994 & 1839 & $34^{\circ} 17.84^{\prime}$ & $118^{\circ} 28.08^{\prime}$ & 10.4 & 4.0 & & & & \\
\hline Jan. 21, 1994 & 1842 & $34^{\circ} 18.53^{\prime}$ & $118^{\circ} 28.18^{\prime}$ & 7.9 & 4.2 & 205 & 55 & 80 & 54 \\
\hline Jan. 21, 1994 & 1852 & $34^{\circ} 18.05^{\prime}$ & $118^{\circ} 27.36^{\prime}$ & 8.9 & 4.3 & 190 & 40 & 60 & 104 \\
\hline Jan. 21, 1994 & 1853 & $34^{\circ} 17.81^{\prime}$ & $118^{\circ} 27.20^{\prime}$ & 7.1 & 4.4 & 215 & 45 & 90 & 53 \\
\hline Jan. 23, 1994 & 0855 & $34^{\circ} 17.65^{\prime}$ & $118^{\circ} 26.01^{\prime}$ & 9.7 & 4.1 & 235 & 45 & 120 & 116 \\
\hline Jan. 24, 1994 & 0415 & $34^{\circ} 20.62^{\prime}$ & $118^{\circ} 33.44^{\prime}$ & 8.9 & 4.6 & 200 & 55 & 110 & 140 \\
\hline Jan. 24, 1994 & 0550 & $34^{\circ} 21.43^{\prime}$ & $118^{\circ} 37.97$ & 12.0 & 4.3 & 180 & 70 & 60 & 126 \\
\hline Jan. 24,1994 & 0554 & $34^{\circ} 21.73^{\prime}$ & $118^{\circ} 38.00^{\prime}$ & 10.9 & 4.2 & 180 & 65 & 70 & 107 \\
\hline Jan. 27, 1994 & 1719 & $34^{\circ} 16.32^{\prime}$ & $118^{\circ} 34.16^{\prime}$ & 16.3 & 4.6 & 230 & 10 & 110 & 132 \\
\hline Jan. 28, 1994 & 0209 & $34^{\circ} 22.22^{\prime}$ & $118^{\circ} 30.13^{\prime}$ & 4.0 & 4.2 & 215 & 35 & 100 & 62 \\
\hline Jan. 29, 1994 & 1120 & $34^{\circ} 18.32^{\prime}$ & $118^{\circ} 34.62^{\prime}$ & 1.6 & 5.1 & 330 & 80 & -20 & 124 \\
\hline Jan. 29, 1994 & 1216 & $34^{\circ} 16.75^{\prime}$ & $118^{\circ} 36.62^{\prime}$ & 3.6 & 4.3 & 140 & 80 & 30 & 102 \\
\hline Feb. 06, 1994 & 1319 & $34^{\circ} 17.15^{\prime}$ & $118^{\circ} 29.04^{\prime}$ & 11.9 & 4.1 & 260 & 10 & -50 & 136 \\
\hline Feb. 25, 1994 & 1259 & $34^{\circ} 21.25^{\prime}$ & $118^{\circ} 29.19^{\prime}$ & 3.7 & 4.0 & 155 & 60 & -80 & 119 \\
\hline Mar 20, 1994 & 2120 & $34^{\circ} 13.57^{\prime}$ & $118^{\circ} 28.90^{\prime}$ & 14.7 & 5.2 & 185 & 50 & 60 & 158 \\
\hline May 25, 1994 & 1256 & $34^{\circ} 18.07^{\prime}$ & $118^{\circ} 23.9^{\prime}$ & 11.6 & 4.4 & 170 & 60 & 70 & 134 \\
\hline Jun. 15,1994 & 0559 & $34^{\circ} 18.11^{\prime}$ & $118^{\circ} 24.11^{\prime}$ & 11.2 & 4.1 & 220 & 45 & 90 & 90 \\
\hline
\end{tabular}

aftershocks. The Santa Susana fault has two lateral ramps, defining lateral separation of the surface trace of the fault, the San Femando lateral ramp (SFLR) on the east side and the Gillibrand Canyon lateral ramp (GCLR) on the west side [Yeats, 1988] (Figure 6). Analysis of drill hole data indicates that the Santa Susana fault has a convex shape and a low dip near the surface [Yeats, 1988].
The available focal mechanisms of the mainshock and 57 aftershocks of $M_{L} \geq 4.0$ are shown in Figure 6 and listed in Table 2. Nearly all of these focal mechanisms show thrust faulting with only a few strike-slip and normal faulting events. The largest aftershock of $M_{L} 5.9$ followed the mainshock within a minute (1231 UT) and was located $10 \mathrm{~km}$ to the east-northeast of the mainshock. No focal mechanism is available for this event. The 


\section{Northridge $1-17: 17.5 \mathrm{~h}$ January 1994 \\ Preshocks, mainshock, and early aftershocks}

(A)

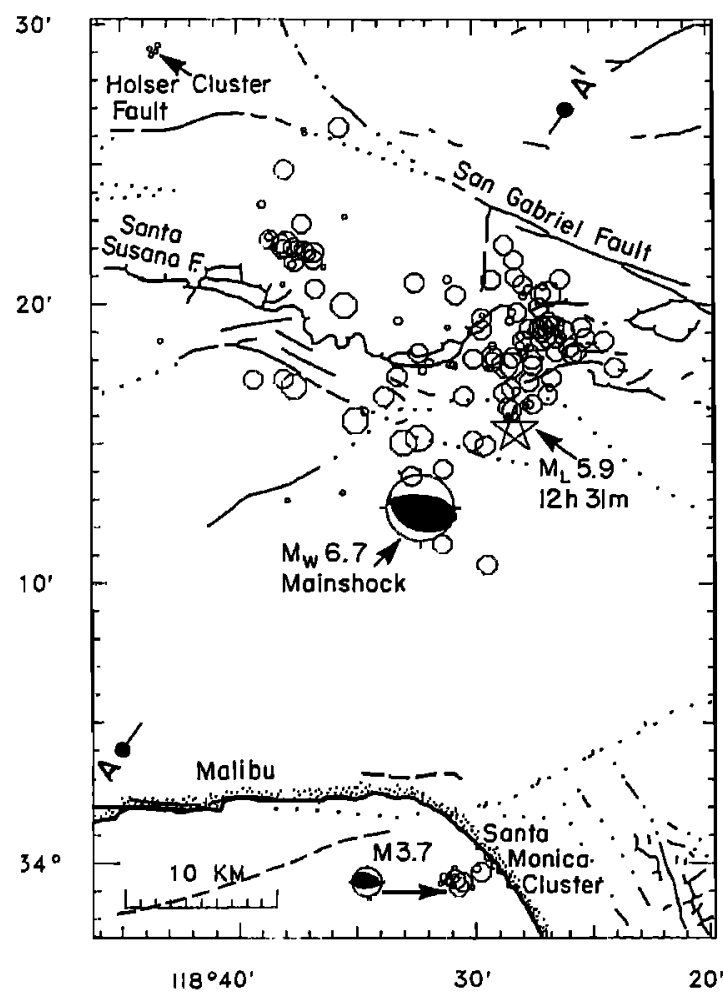

(B)

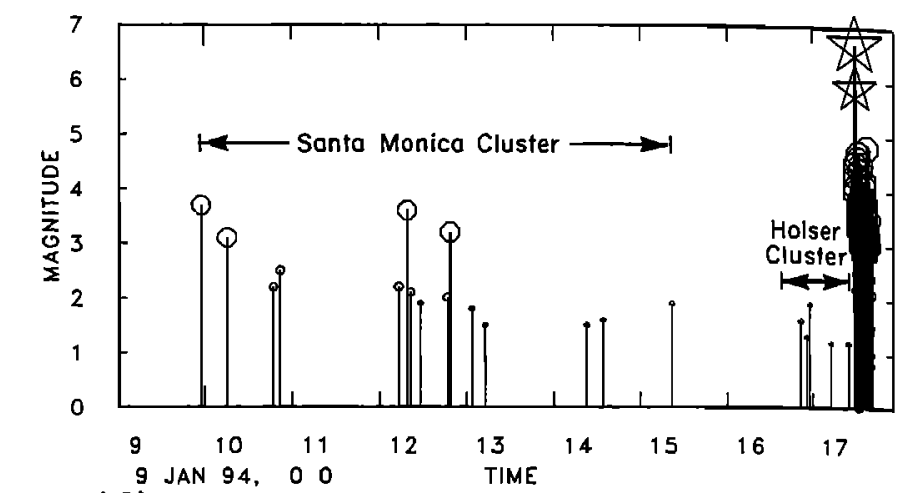

(C)

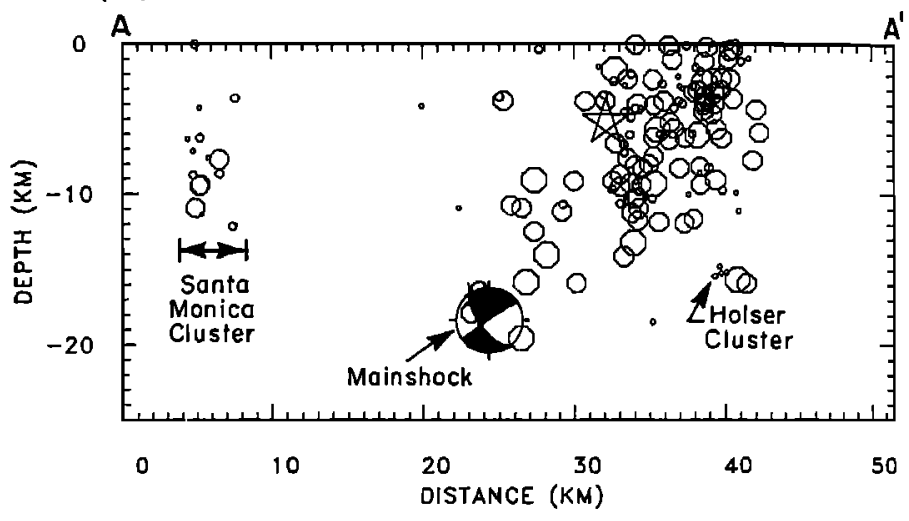

Figure 5. The Northridge mainshock and the two clusters of preshocks located in Santa Monica and near the Holser fault. (a) Map of the preshocks, mainshock, and first 8 hours of aftershock activity. Mainshock is represented by its focal mechanism. (b) Magnitude versus time for the preshocks, mainshock, and early aftershocks. (c) Depth cross section of the preshocks, mainshock, and early aftershocks.

second largest aftershock of $M_{L} 5.6$ occurred 11 hours later (2333 UT) and was located about $20 \mathrm{~km}$ to the northwest of the mainshock. This aftershock had a thrust-faulting focal mechanism similar to the mainshock. This and two other thrustfaulting aftershocks of $M>5$ located near the trace of the Santa Susana fault could be associated with either south or north dipping fault structures.

A cluster of $M_{L} \geq 4.0$ aftershocks was located along the eastern margin of the mainshock rupture plane, about $5 \mathrm{~km}$ to the east of the San Fernando lateral ramp. The San Fernando lateral ramp is a 5-km-long left step in the Santa Susana thrust fault [Yeats, 1988]. This cluster is bounded on the north side by the surface trace of the Santa Susana fault and includes mostly events with thrust mechanisms. However, the largest normal faulting event $\left(M_{L} 4.7\right)$ was located in this cluster.

Another cluster, forming the northwest side of the aftershock zone, also is comprised of mostly events with thrust mechanisms. Several of the larger events of this cluster are located within the Gillibrand lateral ramp, as defined by Yeats [1988], near the northwest end of the Pico anticline. To the west of the Gillibrand lateral ramp the Santa Susana fault steps left and steepens in dip [Yeats, 1988]. A possible tectonic association between these events and adjacent geological features such as the Pico anticline and the Gillibrand Canyon lateral ramp, however, remains unresolved.
Strike-slip deformation has occurred during the late Quatemary along faults such as the Northridge Hills fault and the Mission Hills fault (Figure 6). Three strike-slip $M \geq 4$ aftershocks and several thrust aftershocks are located near the surface trace of the Northridge Hills fault. No large aftershocks were located near the Mission Hills fault, even though significant ground deformation in this region was caused by the Northridge mainshock (USGS and SCEC, 1994). Only one of the eight $M_{L}>5.0$ aftershocks showed a strike-slip focal mechanism, and was located between the surface traces of the Northridge Hills and the Santa Susana faults. Most of the strike-slip and normal faulting aftershocks occurred at shallow depth above the main rupture surface where strike-slip or extensional deformation of the hanging wall may be expected.

\section{Spatial Distribution of Aftershocks}

The 1994 Northridge earthquake and the more than 10,000 aftershocks that occurred from January 17 to September 30, 1994, form a complex spatial distribution. The general geographical shape of the distribution developed within the first 24 hours and did not change significantly during the following 9 months. The only minor change with time that can be seen in space-time plots of aftershocks was the quick decay of aftershock activity located within $5 \mathrm{~km}$ of the western edge of the distribution. The most dense clusters along the Gillibrand Canyon lateral ramp and to the 


\section{Northridge $1994 \quad M \geq 4.0$}

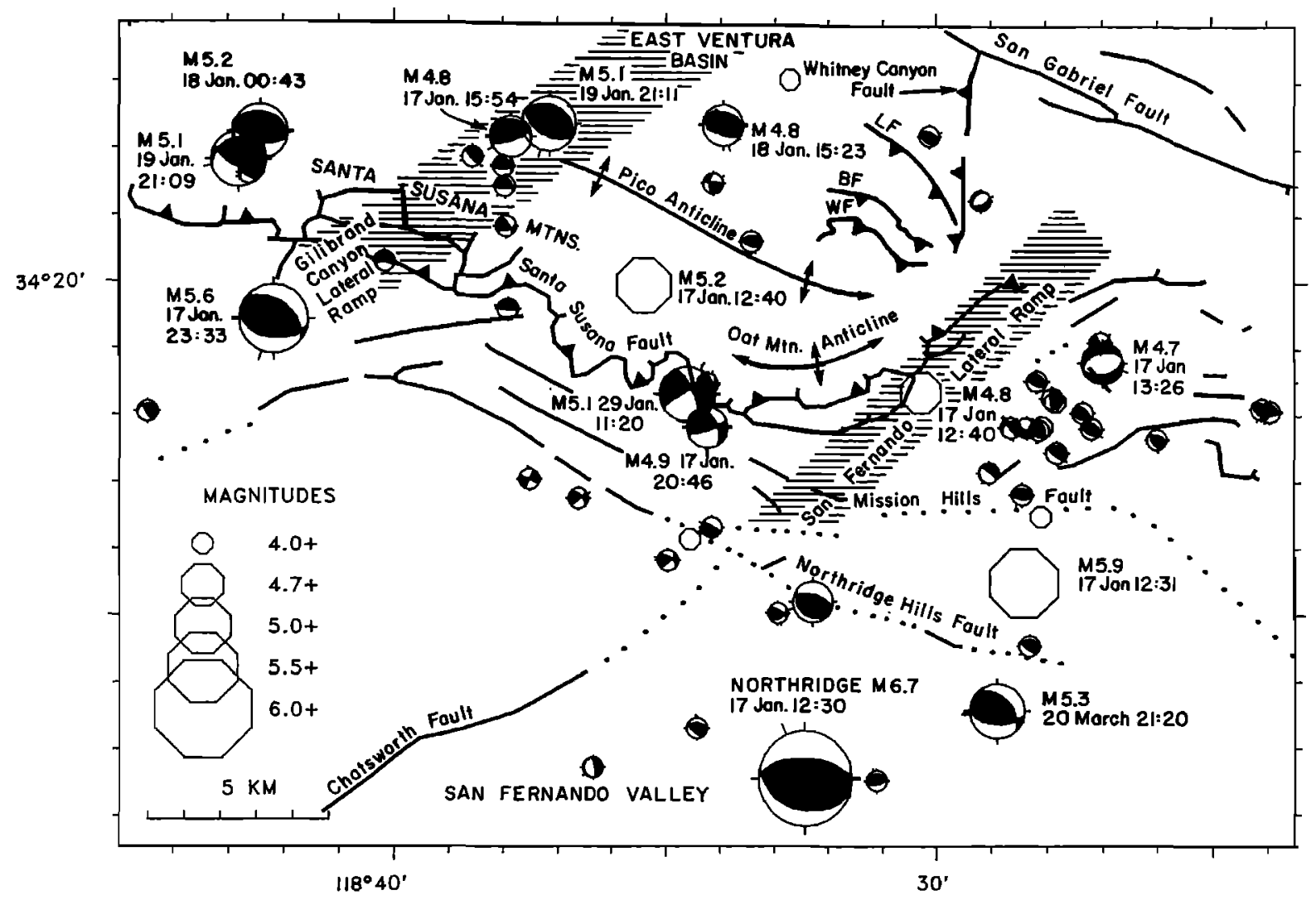

Figure 6. Northridge aftershock region showing lower-hemisphere, first-motion focal mechanisms of $M \geq 4$ earthquakes recorded by the SCSN from January through September 1994, and major faults (dotted where inferred) from Jennings [1975]. Because the $M 5.9$ aftershock occurred too closely in time to the Northridge mainshock or, in several cases, aftershocks were preceded by immediate foreshocks, their focal mechanism could not be determined and their epicenters are shown as open circles.

west of the San Fernando lateral ramp continued to be very active during the first 9 months.

To improve our understanding of how the spatial distribution relates to the mainshock rupture surface and mapped surficial geological features, we show the spatial distribution of the aftershocks with both strike-normal and strike-parallel cross sections. To detect possible spatial changes in the style of aftershock faulting, we show focal mechanisms grouped by style of faulting. In addition, we have drawn schematic spatial contour maps outlining the upper and lower surfaces of the aftershock zone, to summarize how the aftershock distribution changes with depth and along strike.

Strike-normal cross sections. In map view the aftershocks form a 45-km-long and 40-km-wide zone (Figure 7). The mainshock rupture as determined from waveform data [Wald and Heaton, 1994] started at the southeastern comer of this zone near the mainshock epicenter and extended about $15 \mathrm{~km}$ westnorthwest and about $20 \mathrm{~km}$ up a $35^{\circ}-42^{\circ}$ dipping surface to the north-northeast, covering less than one third of the aftershock zone.

Four cross sections extend from south-southwest to northnortheast (Figure 7). The focal mechanisms of the mainshock and representative large aftershocks are included in the map of epicenters and the cross sections. Nearly all of these focal mechanisms are thrust, with only one strike-slip and one normal mechanism.

The cross section D-D' shows aftershocks that occurred along the eastern edge of the mainshock rupture surface. These hypocenters form a south-southwest dipping distribution in the depth range of $5-15 \mathrm{~km}$ with a small number of aftershocks extending down to $20 \mathrm{~km}$ depth. The lower depth bound to the densest part of the aftershock distribution appears to coincide with the steeply dipping Northridge Hills fault (Figure 6). Most of the shallow aftershocks were located near the surface trace of the Santa Susana and Verdugo faults.

The cross section $\mathrm{C}-\mathrm{C}^{\prime}$ includes the hypocenter of the mainshock and shows the $35^{\circ}-40^{\circ}$ dipping zone of aftershocks from $23 \mathrm{~km}$ to about $7 \mathrm{~km}$ depth, located mostly under the San Fernando Valley. If the $35^{\circ}$ south-southwest dipping nodal plane of the mainshock is extended to shallower depths, the rupture surface is located near the lower surface of this dipping aftershock zone. The deep end of this zone is defined by a few aftershocks that extend as deep as $23 \mathrm{~km}$. Above approximately 7 $\mathrm{km}$ depth, the aftershock zone is less well expressed as a southwest dipping tabular feature but is rather a cloud of aftershocks representing diffuse deformation of an overlying anticlinal fold. The San Gabriel fault limits the northeast spatial extent of most of the shallow aftershocks. The southwestern edge 
(A) 1994 Northridge Earth quak e Sequence January - - Sept embe $x$

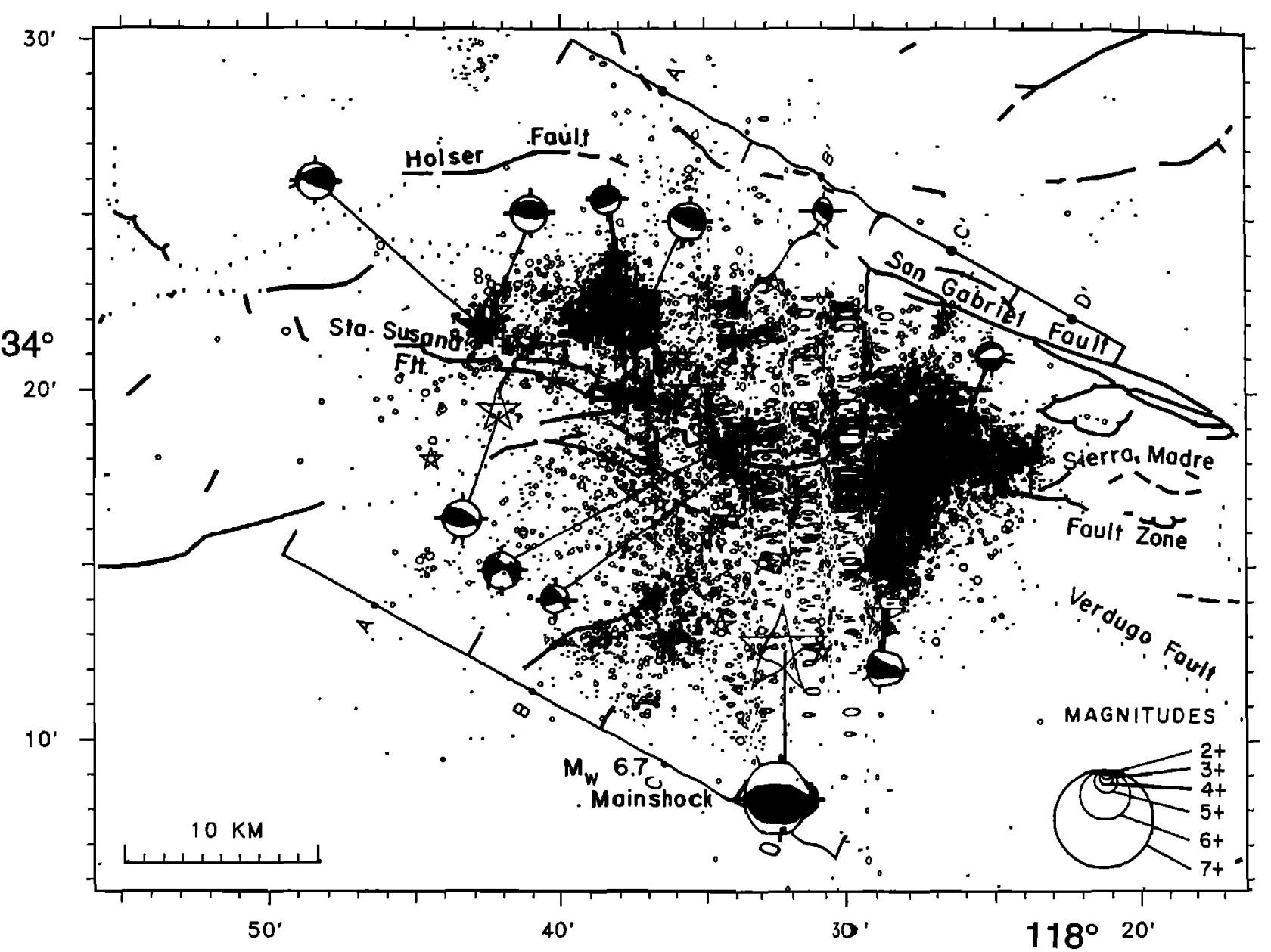

Figure 7. (a) Map of the 1994 Northridge earthquake, its aftershocks, and major late Quaternary faults (dotted where inferred). Focal mechanisms for the mainshock and significant aftershocks are included. Symbol size is scaled with magnitude and earthquakes of magnitude greater than 4 are shown as stars. (b) Depth cross sections taken orthogonal to strike, A-A', B-B', C-C', and D-D' include all events in each box having horizontal and vertical errors less than $2 \mathrm{~km}$. NHF, Northridge Hills fault; SSF, Santa Susana fault; SGF, San Gabriel fault; HF, Holser fault; VF, Verdugo fault; and SFF, San Fernando fault.

of the distribution of shallow aftershocks is located further to the southwest, above the mainshock rupture surface.

Farther to the west, in cross section B-B', the western edge of the mainshock rupture surface is outlined by the south-southwest dipping zone of aftershocks. More distributed deformation of the hanging wall is evident in this section, including shallow events south of the mainshock. A north dipping trend of aftershocks, in the 5-8 $\mathrm{km}$ depth range, may be related to the north dipping Santa Susana fault. The only $M>5$ strike-slip aftershock lies at the eastern edge of this section at shallow depth.

The aftershocks in cross section $A-A^{\prime}$ occurred west of the mainshock rupture surface as defined by waveform modeling [Wald and Heaton, 1994]. They form a diffuse distribution beneath the Santa Susana Mountains and appear to be on different faults that did not rupture in the mainshock. There is some indication in the cross section of a wedge-shaped structure illuminated by both south and north dipping trends of aftershocks in the depth ran ge of $13-18 \mathrm{~km}$. This wedge-shaped structure coincides with the Gillibrand Canyon lateral ramp. The Northridge Hills fault brackets the distribution to the south while the northem edge of the distribution is midway between the Santa Susana and Holser fazlts.

Strike-parallel cross sections. To identify possible steeply dipping distributions of aftershocks with northeasterly strike associated with tear or cross faults we show four cross sections parallel to the strike of the mainshock rupture surface and the major surficial faults in the region such as the Santa Susana and San Gabriel faults (Fi gure 8).

The aftershoclks in the northernmost cross section E-E' are located north of the mainshock rupture. In the central and eastern part of this cross section the aftershocks reach the surface approximately $2-3 \mathrm{~km}$ to the south of the San Gabriel fault. There is also some dee pening of the seismicity beneath the Sylmar basin, down to depths of 5-8 km. A north-northeast trend 

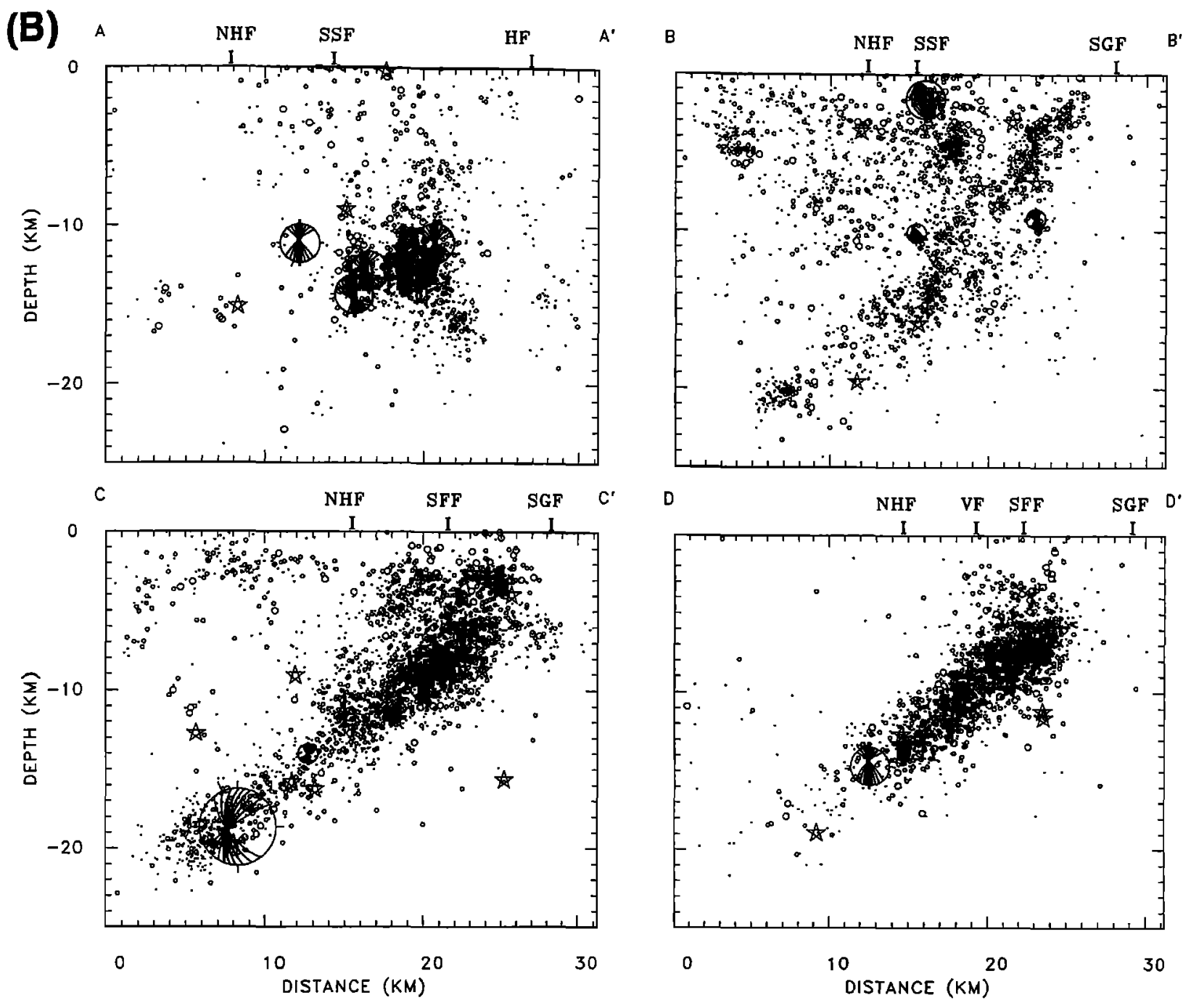

Figure 7. (continued)

of deep seismicity can be seen on the west side, where the surface trace of the Holser fault approaches the surface trace of the San Gabriel fault or near the north end of the Gillibrand Canyon lateral ramp.

The F-F' cross section includes many of the aftershocks above the mainshock rupture surface. On the west side, a steeply dipping distribution is seen extending from the E-E' cross section and is associated with the western edge of the mainshock rupture. This activity could also be associated with the Gillibrand Canyon lateral ramp as defined by Yeats [1988]. An apparent westnorthwest dipping trend of aftershocks, to the east of the surface trace of the Santa Susana fault, may form the lower bound of the Santa Susana Mountains block. In contrast, on the east side of the Santa Susana fault, in part beneath the Sylmar basin, a dense cluster formed the northeastern edge of the mainshock rupture.

In the G-G' cross section, a dense distribution of aftershocks from 8 to $15 \mathrm{~km}$ depth is associated with the upper half of the mainshock rupture surface. At shallower depths the complexity in the aftershock distribution primarily reflects the deformation of the hanging wall. Several large thrust events occurred on the west side of the mainshock fault surface where the mainshock slip was largest [Wald and Heaton, 1994]. Similarly, a dense cluster of small aftershocks also occurred along the eastern edge.
The southernmost cross section $\mathrm{H}-\mathrm{H}$ includes the mainshock hypocenter and the aftershocks surrounding the lower half of the mainshock rupture surface. Similar to cross section G-G', the distribution is also characterized by a cluster of aftershocks in the hanging wall. The deepest aftershocks extended the depth of faulting down to $23 \mathrm{~km}$ depth.

Focal mechanisms. To improve our understanding of the faulting that took place in the 1994 Northridge earthquake sequence, we have determined focal mechanisms for the mainshock and more than 900 aftershocks of $M \geq 2.5$. In Figures $9 \mathrm{a}, 9 \mathrm{~b}, 9 \mathrm{c}$, and $9 \mathrm{~d}$ we show the mainshock and aftershock focal mechanisms for events of $M \geq 2.5$ grouped by depth and type of mechanisms. The events with rake from $45^{\circ}$ to $135^{\circ}$ are thrust, from $-45^{\circ}$ to $-135^{\circ}$ are normal, while all others are strike-slip faulting.

Thrust faulting. The thrust faulting focal mechanisms were split into two groups by depth (Figures $9 \mathrm{a}$ and $9 \mathrm{~b}$ ). The shallow focal mechanisms, in the depth range of $0-9.9 \mathrm{~km}$, show a cluster of events northeast of the mainshock and scattered activity to the north of the Santa Susana fault. Most of these mechanisms have east to east-southeast trending nodal planes. A few thrust faulting events also are located due west of the mainshock epicenter within the hanging wall. Most of these shallow thrust events are 
(A) 1994 Northridge Earthquake Sequence

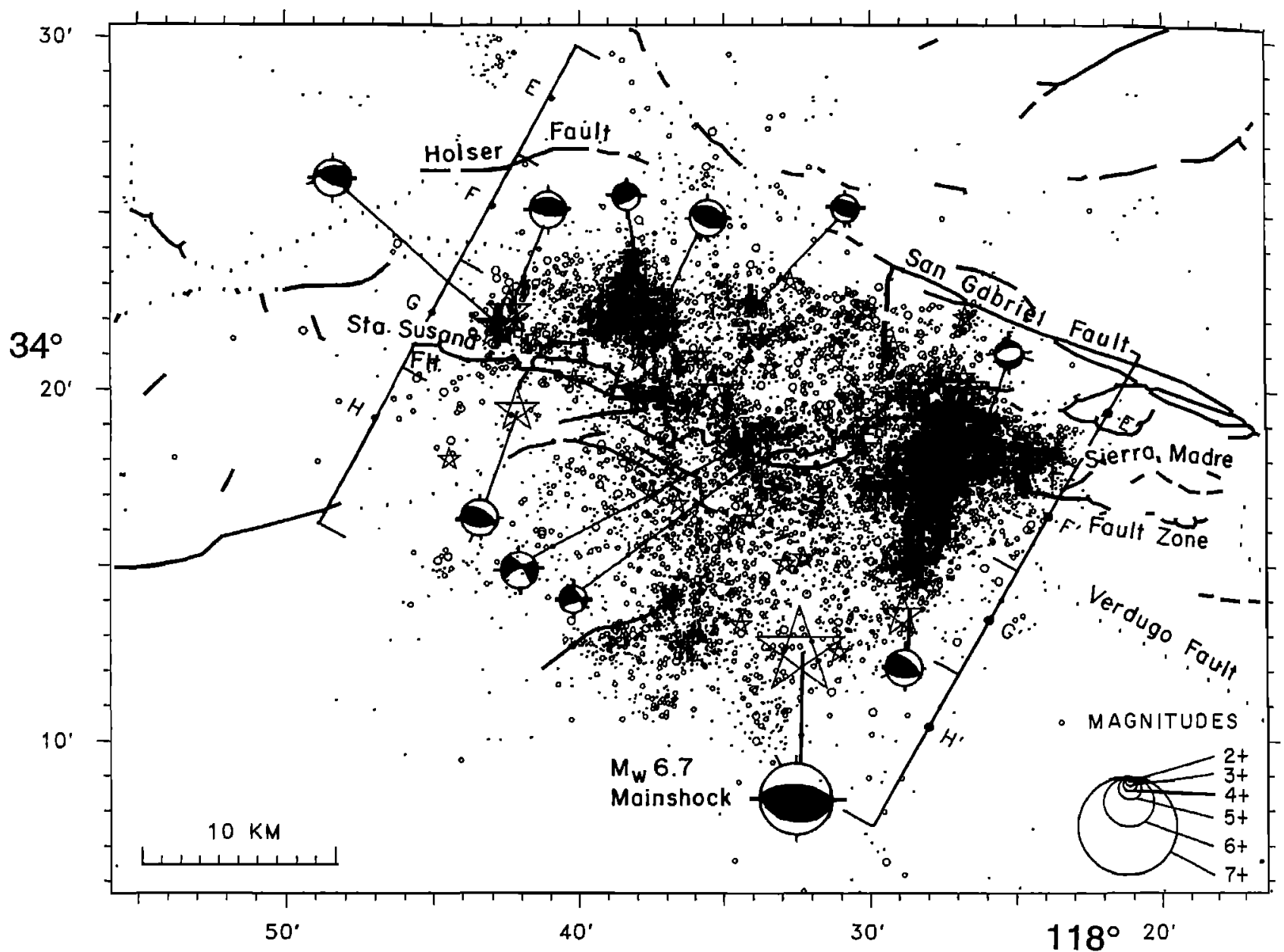

Figure 8. (a) Map of the 1994 Northridge earthquake, its aftershocks, and major late Quaternary faults (dotted where inferred). Focal mechanisms for the mainshock and significant aftershocks are included. Symbol size is scaled with magnitude and earthquakes of magnitude greater than 4 are shown as stars. (b) Depth cross sections taken along strike, E-E', F-F', G-G', and $\mathrm{H}_{-} \mathrm{H}^{\prime}$ include all events in each box and having vertical errors less than 2 km. SSF, Santa Susana fault; SGF, San Gabriel fault; GCLR, Gillibrand Canyon Lateral Ramp; and CWF, Chatsworth fault.

associated with small secondary faults in the hanging wall and contribute to the formation of the fold above the mainshock fault at depth. A few of these events have one subhorizontal nodal plane, suggesting that some of the faulting may be occurring on subhorizontal surfaces.

The thrust focal mechanisms in the depth range of 10 to $23 \mathrm{~km}$ are shown in Figure 9b. These events form two spatially distinct clusters. One is located adjacent to the mainshock and extends about 12-15 km to the north, toward the surface trace of the Santa Susana fault. These events also reflect the south-southwest dip of the mainshock fault. The second cluster is located to the west of the mainshock and to the north of the surface trace of the Santa Susana fault. This cluster most likely illuminates secondary faults that began breaking during the hours following the mainshock.

Strike-slip faulting. The strike-slip faulting aftershocks showed movement along north to north-northwest trending planes (Figure 9c). A prominent 15-km-long linear trend of strike-slip faulting aftershocks can be seen subparallel to the Northridge Hills fault. Several other trends can be seen, although none appear to be longer than about $5 \mathrm{~km}$. The strike-slip faulting extends from the near surface down to depths of $18-20 \mathrm{~km}$. The short trends of strike-slip mechanisms show both right and left lateral faulting. The coexistence of left-lateral and right-lateral strike-slip faulting or possibly conjugate faulting has also been observed in other southern California sequences [e.g. Haukssom 1994a].

Normal faulting. The normal faulting occurred primarily along north to northeast striking planes. A few normal faulting events have northwest striking fault planes. The normal faulting events are located north of the mainshock rupture. Most of the normal events are shallow, although a few are in the depth range of 10-23 km. They occur in regions where there are also strikeslip faulting aftershocks. This indicates that the extensional strains in the hanging wall imposed by the mainshock were released by both normal and strike-slip faulting aftershocks. 

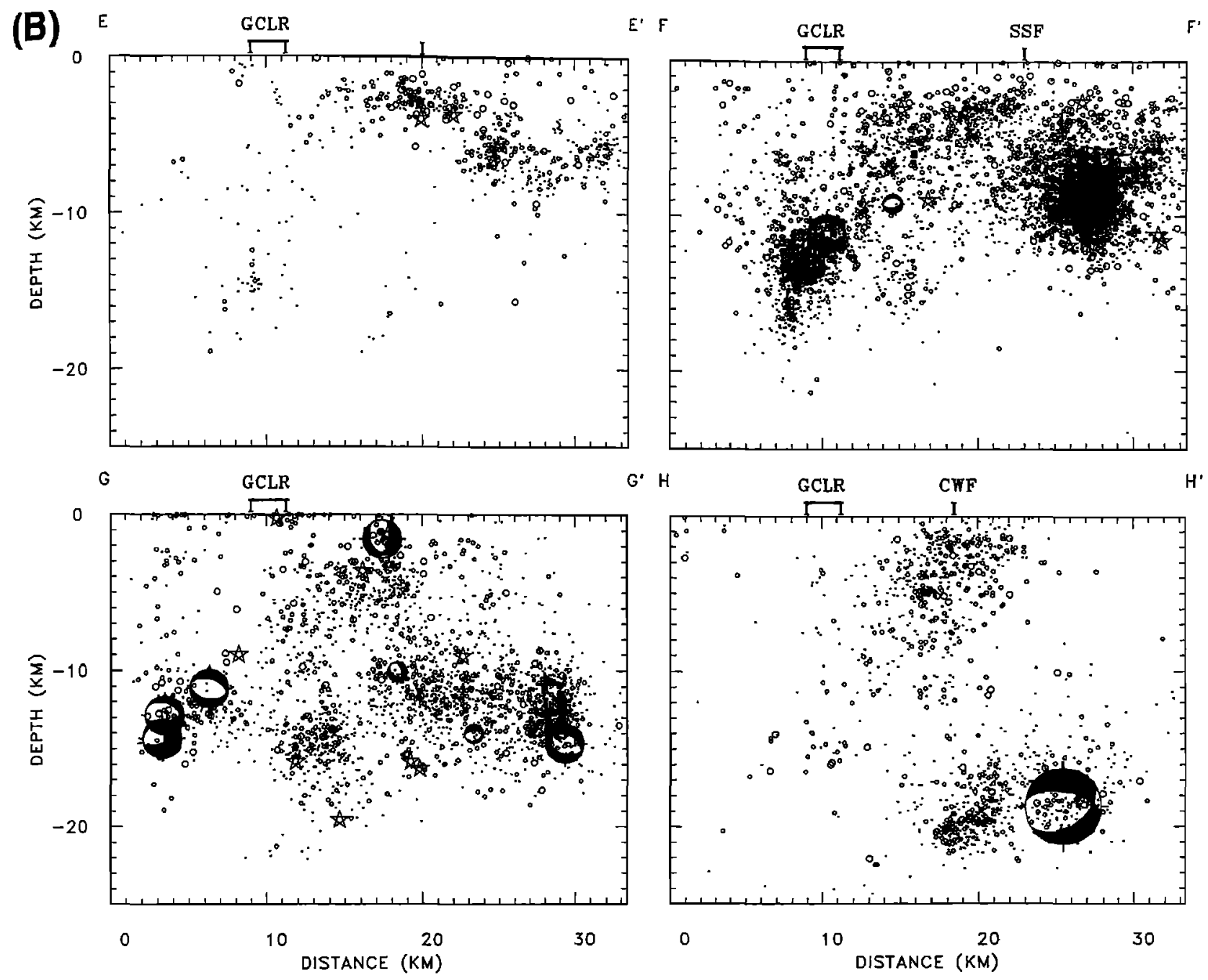

Figure 8. (continued)

Structural contours. To illustrate variations in the aftershock distribution along strike and with depth, we have drawn schematic structural contours outlining the depth to the top and bottom of the aftershock zone (Figure 10). Ten maps, each showing aftershocks in a $2 \mathrm{~km}$ depth interval, were visually inspected to infer the bottom and top of the aftershock zone. Aftershocks occurring within the hanging wall were ignored to simplify the contour plots. We have superimposed these contours on top of maps of the late Quaternary surficial faults in the region.

At depths shallower than $9 \mathrm{~km}$, the contours outlining the depth to the top of the distribution follow the general strike of the Santa Susana fault (Figure 10a). Within the $3 \mathrm{~km}$ depth contour the aftershock zone extends to the surface. Near the western end the contours are closer together, indicating steeper dip in the depth range from 3 to $13 \mathrm{~km}$. In the depth range of 17 to $21 \mathrm{~km}$ the contours are closer together than in the depth range of 11 to 17 $\mathrm{km}$, indicating the termination of the zone of aftershocks at a depth of 21 to $23 \mathrm{~km}$.

The shape of the contours of the base of the aftershock distribution is more strongly correlated with the near-surface geology than the top of the distribution. The most prominent effects on the base of the aftershock zone are from the San
Fernando and the Gillibrand Canyon lateral ramps. Both of these lateral ramps were previously mapped because they offset the north-dipping Santa Susana fault [Yeats, 1988]. The structure contours indicate that the lateral ramps bound a ridge in the fault zone that is about $3-5 \mathrm{~km}$ higher than the surrounding region in the depth range of 7 to $15 \mathrm{~km}$. The structure contours also indicate that the dip of the base of the aftershock zone steepens from east to west (Figure 10).

When overlain over the basal contours, the finite rupture model of Wald and Heaton [1994] shows how the rupture may terminate as it reached the 11 to $9 \mathrm{~km}$ depth contours (Figure 10b). The two major areas of slip occurred downdip of the ridge near the hypocenter, and on top of the ridge at depths of 10-15 km. We speculate that the presence of the ridge may have limited the spatial extent of the rupture to the west.

Both the top and bottom contours indicate that the aftershock zone is more steep to the west than to the east. The mainshock rupture was confined to the part of the fault surface that had the shallowest dip. The contours also show that the distribution of aftershocks does not flatten out below the mainshock hypocenter or below $19 \mathrm{~km}$ depth, thus providing no positive evidence of the existence of a low-angle detachment.

In summary, the complex aftershock distribution exhibits 


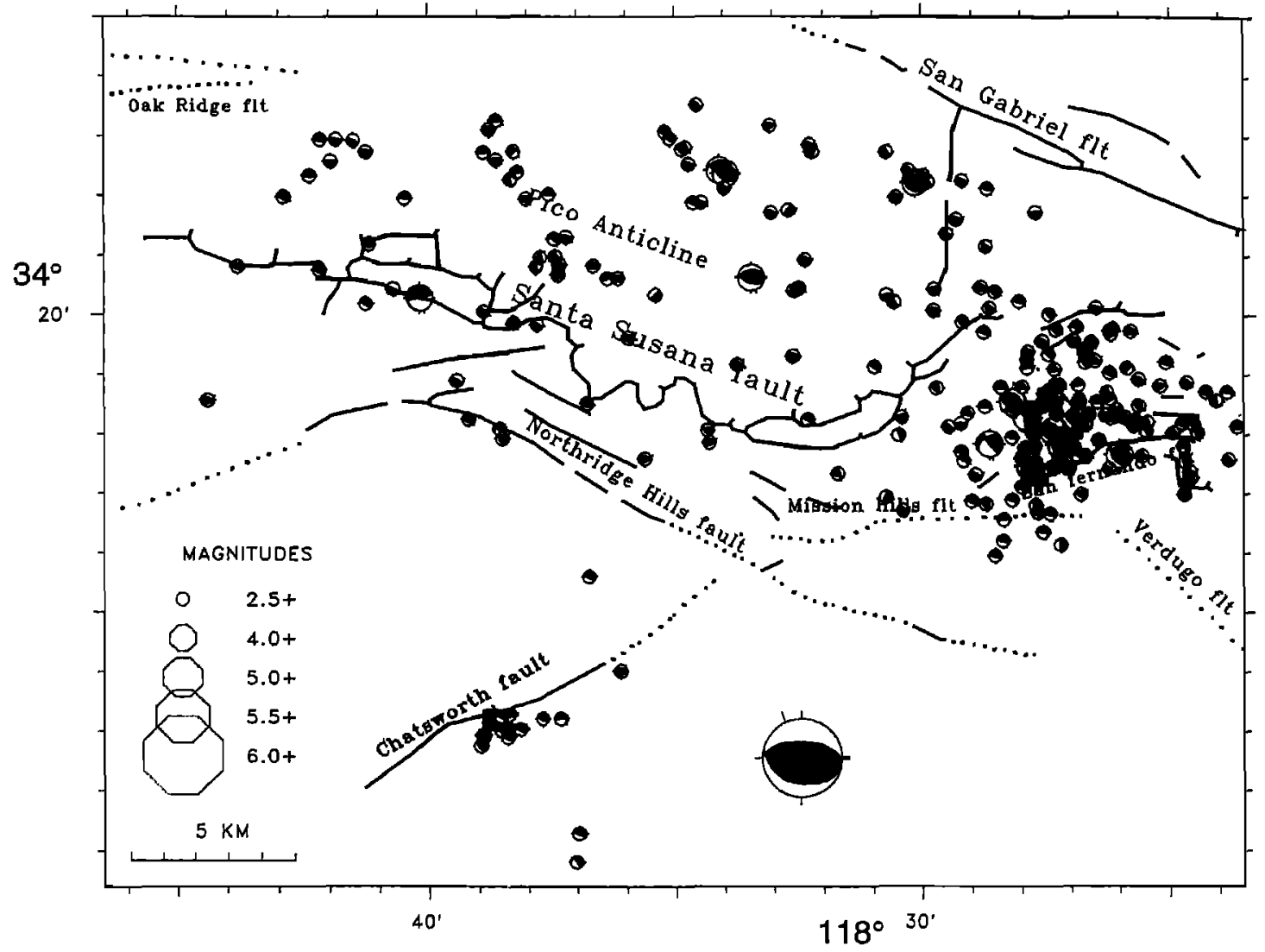

(B)

Thrust; Depth: $10.0-23.0 \mathrm{~km}$

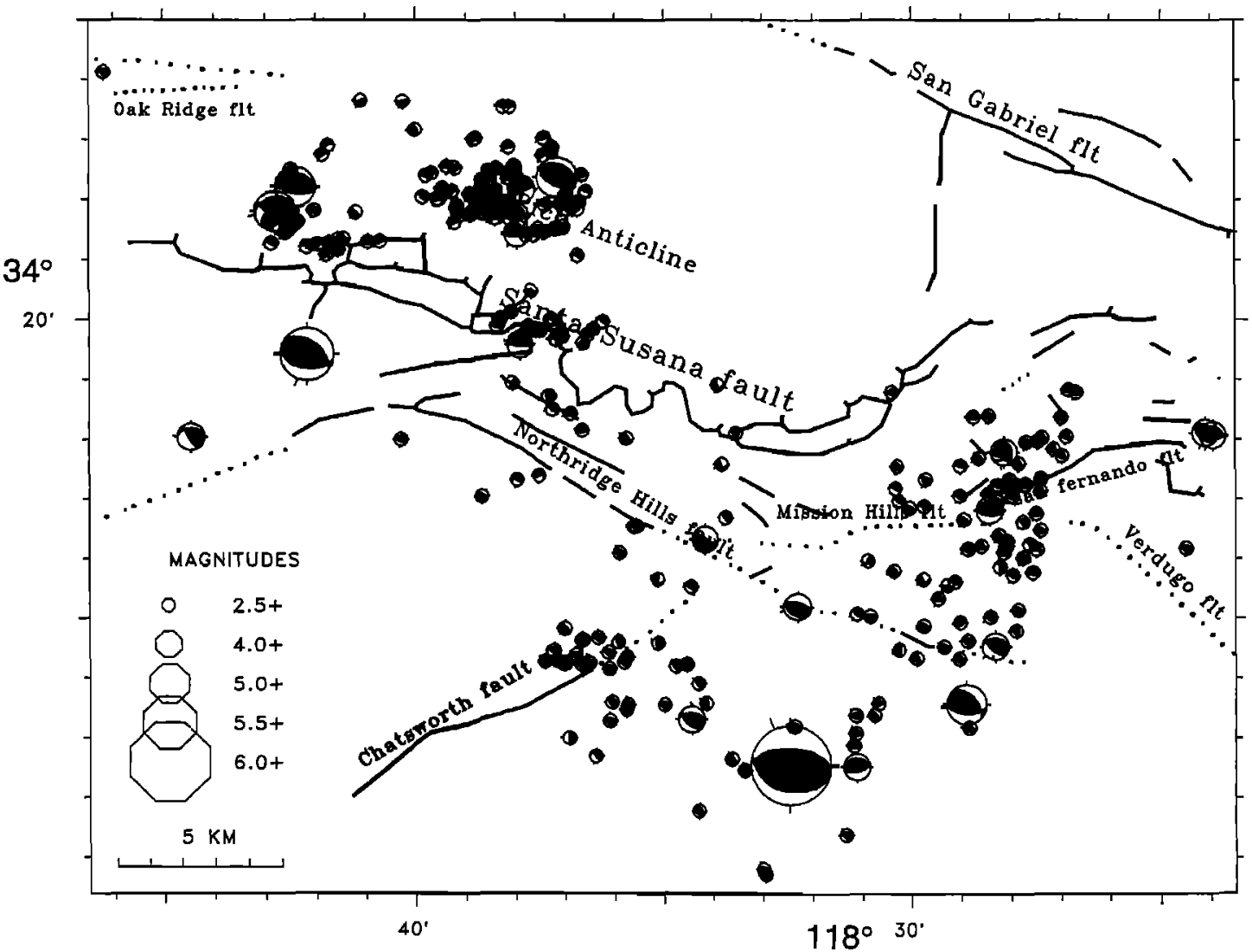

Figure 9. Map of the focal mechanisms of earthquakes $(M \geq 2.5)$ of the Northridge sequence. (a) Focal mechanisms showing thrust faulting in the depth range $0-9.99 \mathrm{~km}$. (b) Thrust faulting in the depth range 10.0-23.0 $\mathrm{km}$. (c) Strike-slip faulting in the depth range $0.0-23.0 \mathrm{~km}$. (d) Normal faulting in the depth range 0.0-23.0 km. 
(C)

Strike-slip; Depth: $0.0-23.0 \mathrm{~km}$

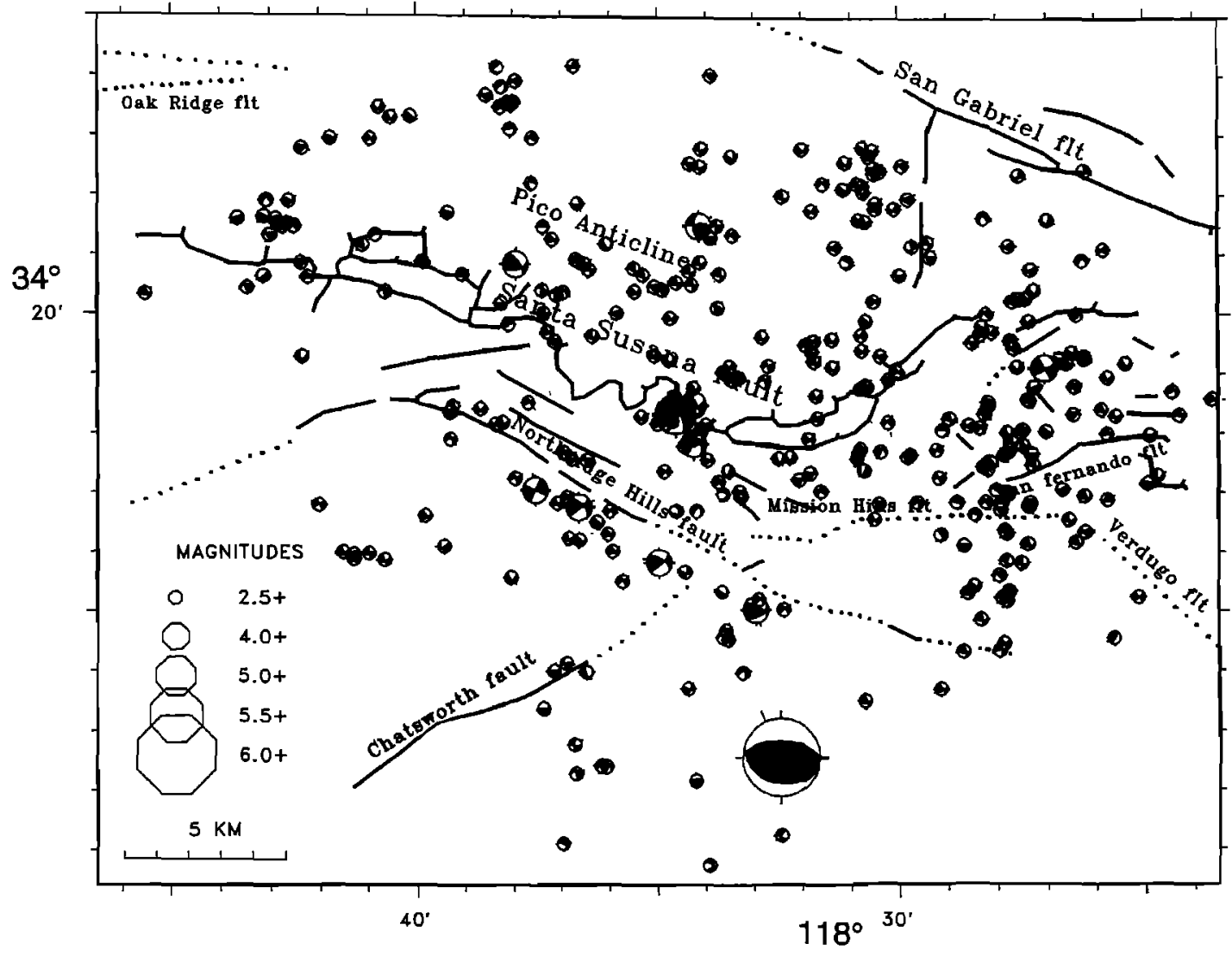

(D)

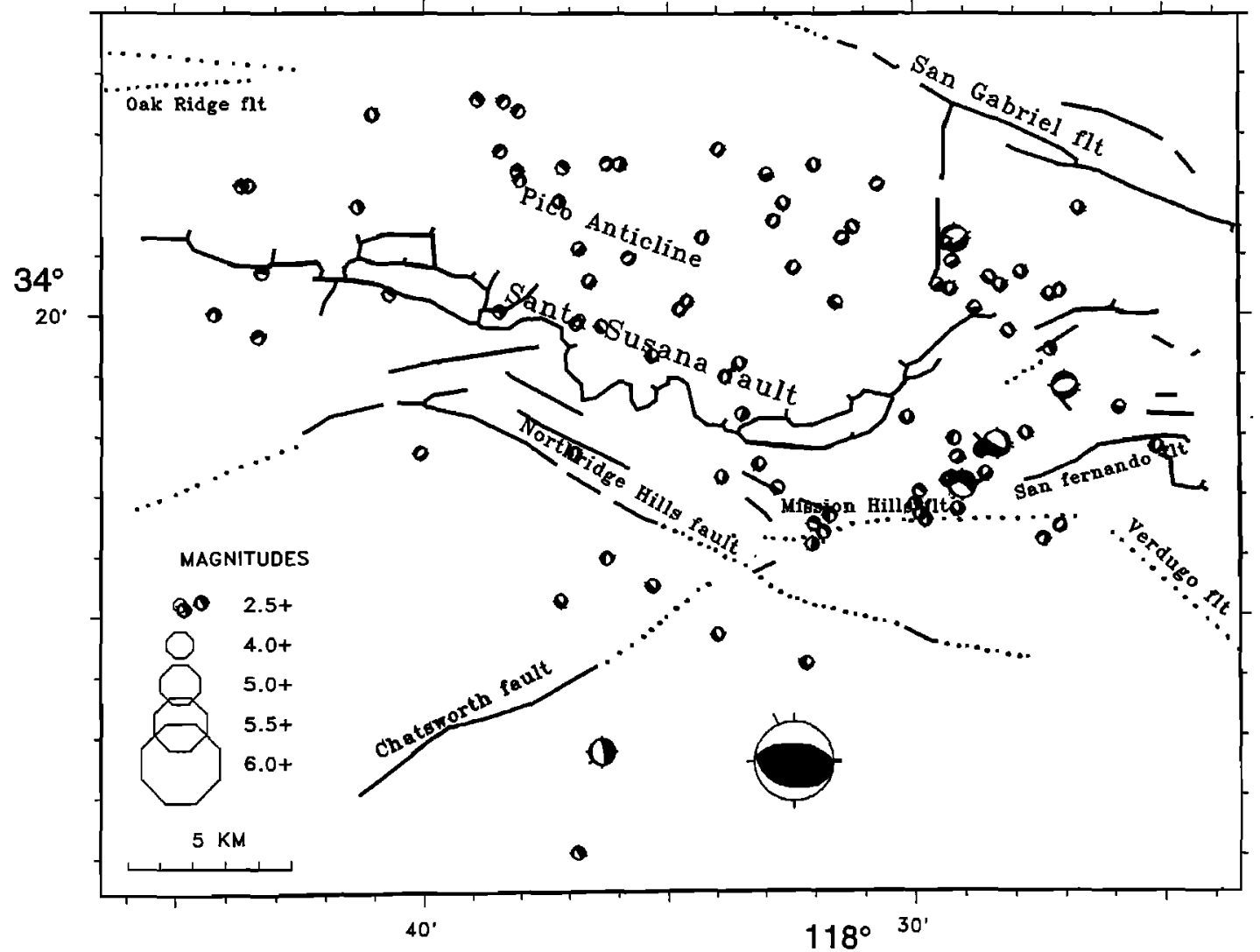

Figure 9. (continued) 


\section{(A)} Depth to Top of Aftershock Zone

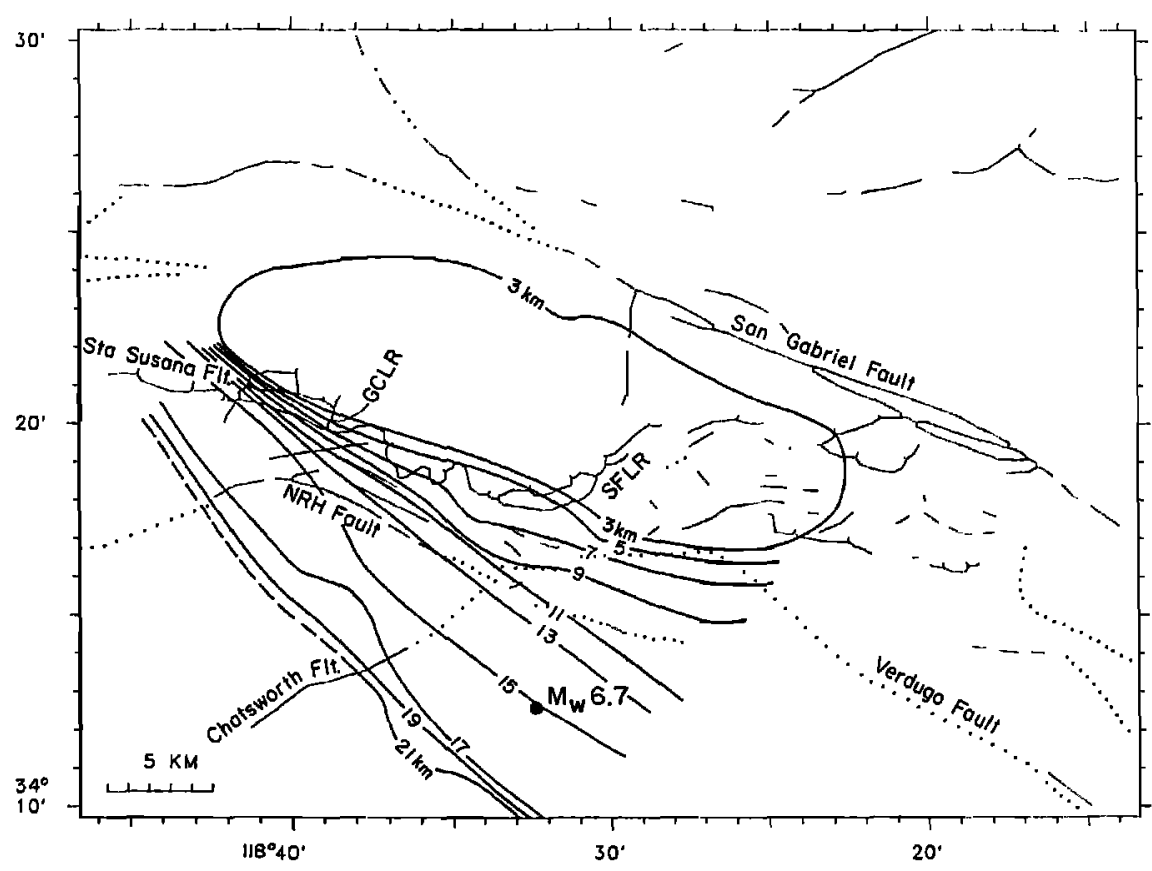

(B) Depth to Bottom of Aftershock Zone

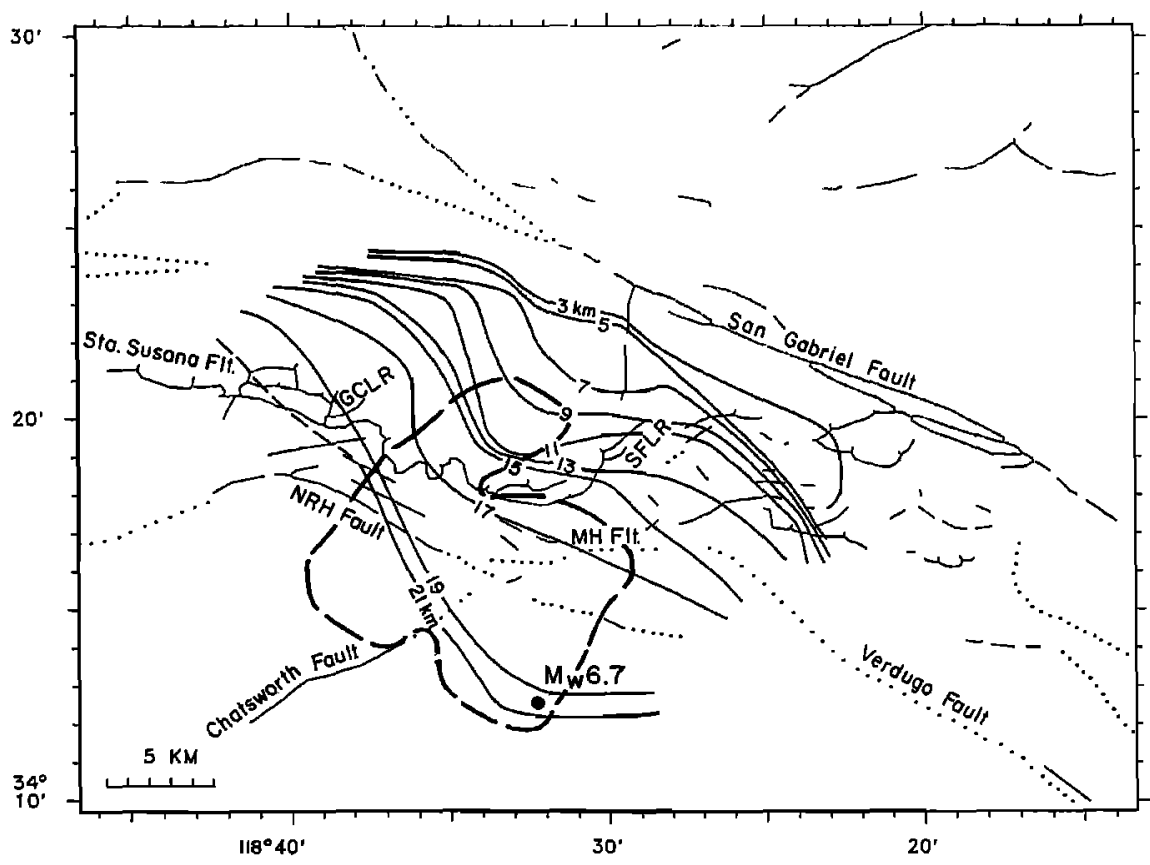

Figure 10. Schematic structural contours determined from the spatial distribution of the Northridge aftershocks showing (a) depth to the top of the aftershock zone when excluding the events within the hanging wall and (b) the depth to the lower surface of the aftershock zone including contours enclosing areas of slip from Wald and Heaton [1994]. The hypocenter of the $M_{W} 6.7$ mainshock is indicated with a solid circle.

several major distinctive features. First, the southwest-dipping zone of aftershocks is consistent with the focal mechanism of the mainshock and finite rupture models of the mainshock. Second, mapped surficial faults appear to bound crustal blocks where most of the aftershocks occurred. Third, the hanging wall deformation appears to indicate some extensional deformation as evidenced by a small component of normal and strike-slip motion in the focal mechanisms. Fourth, the distribution of aftershocks along the western and eastern edges of the rupture zone are distinctively different. The aftershocks along the westem edge form a north-northeast striking and steeply dipping structure with mostly thrust faulting on east-striking planes. This cluster 
extends from depths of 12 to $18 \mathrm{~km}$. Along the east side, the aftershocks form a dense cluster extending from the surface down to depths of $12 \mathrm{~km}$. The aftershocks occurring along the east side also exhibited primarily thrust faulting focal mechanisms. In general, thrust faulting focal mechanisms were most common and the aftershocks did not show much diversity in the types of focal mechanisms. This is different from some other earthquakes, where large coseismic changes in the regional stress field have been used to explain anomalous focal mechanisms [e.g., Beroza and Zoback, 1993; Hauksson, 1994a].

\section{Relation to the 1971 San Fernando Earthquake}

Both the $M_{w} 6.71971$ San Fernando and the $M_{w} 6.71994$ Northridge earthquakes contributed to the tectonic process of north-south contraction and uplift of the Transverse Ranges (Figure 11). The hypocenters of the 1971 sequence are determined from phase data from SCSN, for 1971 and 1972, and portable instruments, for the time period February to April 1971 [Mori et al., 1995]. The 1971 hypocenters were relocated using the new Northridge velocity model. In detail, both sequences have different characteristics in terms of the faulting process and their seismological properties.

The details of the seismicity preceding both sequences differed significantly. The 3 weeks prior to the Northridge earthquake were marked by the Santa Monica Bay and the Holser clusters. No similar preshocks were observed during the 3 weeks prior to the 1971 San Fernando earthquake [Ishida and Kanamori, 1978].

The 1971 San Fernando earthquake ruptured the northnortheast dipping San Fernando fault from 12-15 km depth up to the surface [e.g., Heaton, 1982]. The initiation of the depth of faulting in the San Fernando earthquake that was constrained both with waveform modeling [Heaton, 1982] and with arrival time data was $4-8 \mathrm{~km}$ shallower than for the Northridge earthquake. Using additional arrival times from strong motion instruments, Hadley and Kanamori [1977] obtained an improved hypocentral location of $34^{\circ} 25.45^{\prime} \mathrm{N}$ and $118^{\circ} 22.63^{\prime} \mathrm{W}$ at a depth of $11.5 \mathrm{~km}$. The San Fernando aftershocks were distributed around the mainshock fault plane, which had a strike of $N 67^{\circ} \mathrm{W}$, dip of $52^{\circ}$, and rake of $72^{\circ}$ based on the first-motion focal mechanism [Whitcomb et al., 1973]. In addition, Whitcomb et al. [1973] used aftershock hypocenters and focal mechanisms to identify a westside-down step in the mainshock rupture plane along a northeast trending tear (the Chatsworth trend). In contrast, the Northridge rupture started at $19 \mathrm{~km}$, terminated at $8 \mathrm{~km}$, and no strike-slip tear faulting is apparent.

The 1994 Northridge $M_{L} \geq 4.0$ aftershocks were located near the edges of the aftershock zone and mostly exhibited thrust focal mechanisms. This is in contrast to the large aftershocks of the $1971 M_{w} 6.7$ San Fernando earthquake that had a variety of mechanisms at the edge of the mainshock rupture as well as a trend of left-lateral strike-slip deformation extending to the southsouthwest toward the Chatsworth fault [Whitcomb et al., 1973].

The 1971 San Fernando and the 1994 Northridge earthquakes ruptured partially abutting fault surfaces on opposite sides of a ridge [Mori et al., 1995]. The Northridge rupture was deeper and possibly bounded on the updip side by the north-northeast dipping fault systems that ruptured in 1971. The epicenters of the 1971 San Fernando and 1994 Northridge earthquakes are located about $26 \mathrm{~km}$ apart along a northeast trending line (Figure 11). The actual rupture surfaces do not crosscut each other. Although their aftershock zones abut, they do not overlap in any significant way, suggesting that none of the faults activated in 1971 were reactivated in 1994. Even though the Chatsworth trend extends into the Northridge aftershock zone, it is confined within the hanging wall, above the mainshock rupture surface and the deeper distribution of 1994 aftershocks.

\section{Aftershock Statistics}

Aithough the Northridge aftershock sequence is dying off slightly more quickly than average, it is also more active than most Califomia aftershock sequences. For comparison, the 1971 San Femando sequence was smaller than average, and the 1933 Long Beach sequence was even more energetic than Northridge (USGS and SCEC, 1994).

Because the decay of the Northridge sequence is rapid, the number of aftershocks expected in 1995 is small compared to the total sequence. The $p$ value of the Northridge sequence was 1.2, which is somewhat higher than the average of 1.08 for California sequences [Reasenberg and Jones, 1989]. We expect only 18 earthquakes of $M \geq 3$ and two of $M \geq 4$ in 1995. The probability of an aftershock of $M \geq 5$ in 1995 is only $25 \%$ as determined with the technique developed by Reasenberg and Jones [1989].

\section{Discussion}

In several respects, the Northridge earthquake was a surprise. It occurred on a deep concealed south-southwest dipping thrust ramp beneath the San Fernando Valley, it was not obviously associated with any surficial geological features such as Quaternary folds, and its location was close to the location of the 1971 San Fernando earthquake. Despite these unexpected aspects, however, earthquake activity was anticipated (USGS and SCEC, 1994) because the seismicity rate in the Los Angeles area has been anomalously high in the past 25 years (Figure 12). Furthermore, the known earthquake deficit associated with concealed faults strongly suggested that large earthquakes should be expected in the greater Los Angeles region [Hauksson, 1992].

\section{Surficial Geological Signature of the Ramp}

Unlike previous earthquakes on blind thrust faults in California, the Northridge earthquake is not obviously associated with any surficial geological structures. No surface faulting was observed because fault rupture terminated at a depth of $7 \mathrm{~km}$. The uplift associated with the mainshock was centered at the northern edge of the San Fernando Valley [Hudnut et al., 1996] and did not coincide directly with a Quaternary anticline or another type of a topographic high. Although the Pico anticline fortuitously has the same strike as the mainshock fault plane, the fold is located $8 \mathrm{~km}$ to the north of the region of maximum uplift [Hudnut et al., 1996].

The Oak Ridge fault, a south dipping reverse fault in the central and western Transverse Ranges with a slip rate of approximately $5 \mathrm{~mm} / \mathrm{yr}$, may affect the tectonics of the epicentral area (Figure 1) [Yeats, 1988; Yeats and Huftile, 1994]. The Oak Ridge fault has been mapped along the southern edge of the Ventura basin, from the Santa Barbara channel, to the western end of the Santa Susana fault, and it defines the southern edge of the Santa Clara Valley. Further east, the Oak Ridge fault may extend beneath the Santa Susana fault, and thus its interaction with the Santa Susana fault and its role in the active tectonics of the epicentral region are ambiguous.

The common assumption that all large Califomia earthquakes are associated with obvious surficial geological faults or folds [Stein and Yeats, 1989] thus may not apply to the Northridge earthquake. In the case of the Northridge earthquake, the 

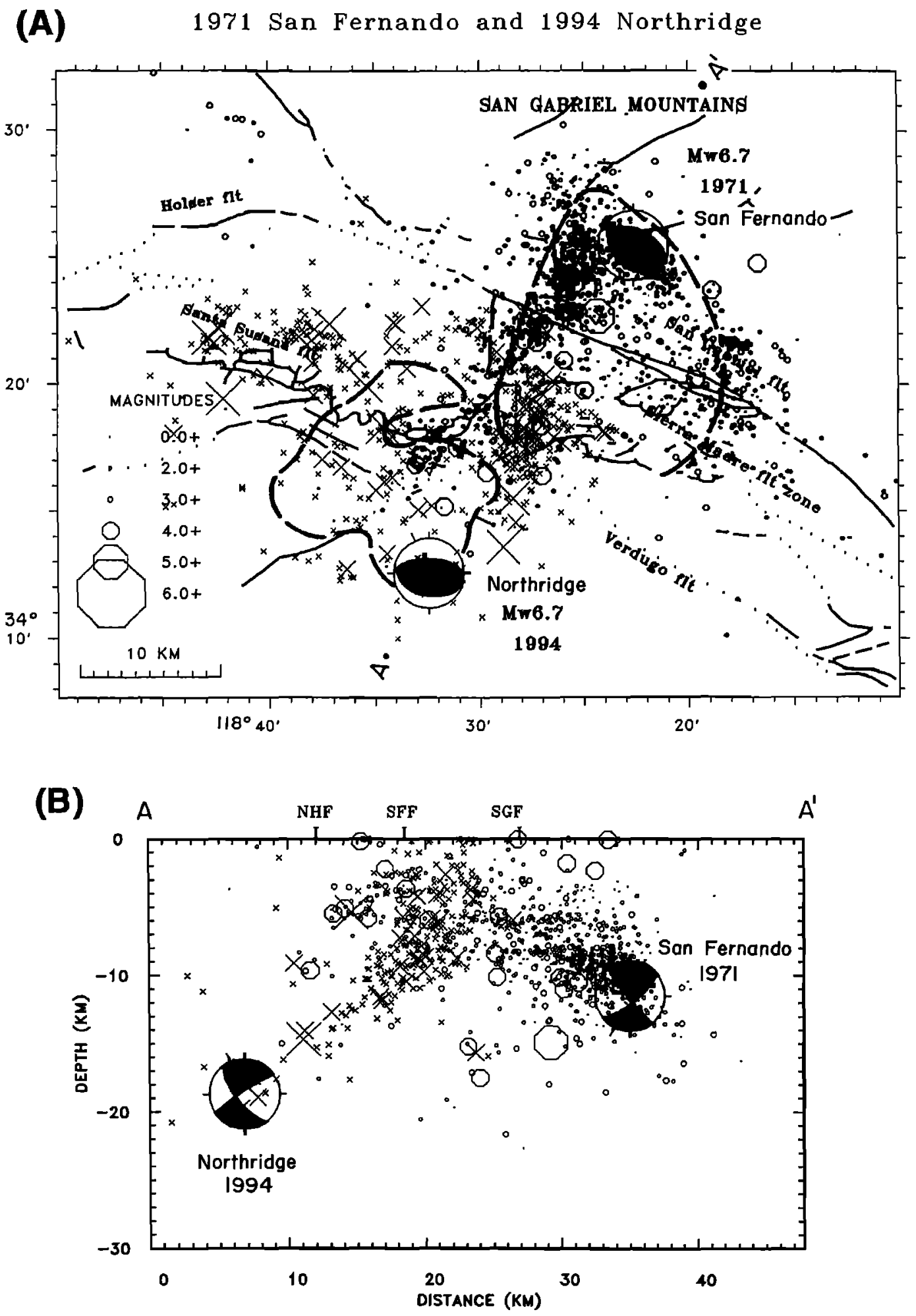

Figure 11. (a) Map and (b) northeast striking cross section showing both the 1971 San Fernando (open circle symbols) and the 1994 Northridge aftershocks (crosses). Aftershock data are from portable instruments, February to April 1971 [Mori et al., 1995], and SCSN data from 1971 and 1972. Approximate rupture surfaces for the 1971 [Heaton, 1982] and 1994 [Wald and Heaton, 1994] earthquakes are also shown.

cumulative slip on the thrust ramp may be so small that a perceptible fold has not yet formed. Alternatively, the movement on other geological structures may be more rapid and may complicate the surficial expression on this new fold.

\section{Subhorizontal Detachment?}

Previously identified north dipping reverse faults such as the Santa Susana and Sierra Madre faults at the base of the east-west 
Temporal Distribution

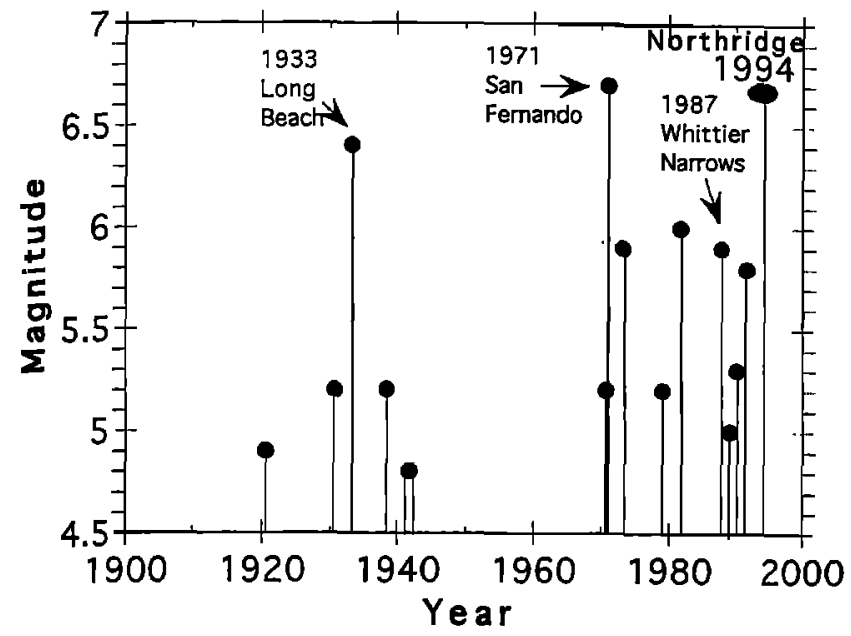

Figure 12. The temporal distribution of $(M \geq 4.8)$ mainshocks in the greater Los Angeles region since 1900.

trending mountains are the principal structures responsible for generating uplift and the local high topography [e.g., Dibblee, 1982]. The mountains are also uplifted by concealed north dipping thrust ramps, such as the thrust ramp beneath the Santa Monica Mountains, which also had been previously identified [Namson and Davis, 1992]. Movement on the south dipping thrust ramp that caused the Northridge earthquake, deep beneath the middle of the San Fernando Valley, also caused uplift of the mountains and the floor of the San Fernando Valley. The south dipping thrust ramps probably play a smaller role in the overall deformation of the region than the north dipping structures.

All of these faults have been postulated to root in a subhorizontal decollement based on both seismological and geological data [e.g., Hadley and Kanamori, 1977; Davis and Namson, 1994]. The regional seismicity and $M \geq 3.5$ aftershocks following the 1971 San Fernando earthquake were analyzed by Hadley and Kanamori [1977]. Because the two deepest events at focal depth of 12-14 km had focal mechanisms with one subhorizontal nodal plane, they inferred a subhorizontal decollement below the San Fernando Valley at depth of about 15 $\mathrm{km}$. Webb and Kanamori [1985] also suggested that a subhorizontal decollement was present based on a few more mechanisms with one subhorizontal nodal plane. In some cases the Northridge aftershocks also had subhorizontal planes in this depth range, consistent with the presence of subhorizontal faults but only of limited spatial extent.

The 1994 Northridge earthquake was at least $5 \mathrm{~km}$ deeper than any of the previous focal mechanisms with subhorizontal nodal planes. Thus, if there is a regional detachment at the base of these crustal ramps, it must be as deep or deeper than $20 \mathrm{~km}$. Because the Northridge aftershock distribution does not flatten in the depth range of $17-21 \mathrm{~km}$, it provides no evidence for the presence of a subhorizontal regional detachment. Thus these seismological data to some extent favor the latest tectonic modeling by Yeats [1993] who proposed that crustal thickening, not horizontal detachments, may be the important mechanism for accommodating horizontal compression in the Ventura region. Otherwise, a regional detachment would need significantly more topographic relief than suggested by existing models [Namson and Davis, 1992].

\section{Seismic Hazard}

The 1994 Northridge earthquake reemphasized the seismic hazard of concealed faults, which we have recognized more fully since the 1987 Whittier Narrows earthquake [Hauksson et al., 1988]. The Northridge earthquake occurred at a greater depth than any previous large earthquake in this region. It began rupturing at $19 \mathrm{~km}$ and terminated upward at a depth of $7 \mathrm{~km}$ [Wald and Heaton, 1994]. The upper limit of the rupture is similar to what has been reported for some of the previous earthquakes in the region [Hauksson, 1994b]. This relatively large depth extent of the Northridge earthquake shows that the seismogenic width of faults and thrust ramps in the Los Angeles area may be $5-10 \mathrm{~km}$ larger than previously estimated [Ziony and Yerkes, 1985]. This large seismogenic width in tum increases the size estimate of maximum possible earthquakes. This means that many fairly short fault segments may rupture in larger earthquakes than previously thought.

Surficial mapping may identify all potential sources of $M>7$ earthquakes, while some source zones of $M<7$ earthquakes go undetected. The occurrence of a Northridge-sized earthquake that can radiate damaging ground motions over a large area (USGS and SCEC, 1994) thus needs to be included as a random event in seismic hazards calculations.

The spatial distribution of the aftershocks illuminates structures previously unmapped at depth. Nearly all of these structures are accommodating north-south contraction. The bulk of the deformation is accommodated by west or north-northwest striking thrust faults dipping both south and north. The absence of a large component of oblique faulting in the mainshock or significant secondary strike-slip faulting in the aftershocks as was reported for the 1971 San Femando [Whitcomb et al., 1973] and 1987 Whittier Narrows [Hauksson and Jones, 1989] earthquakes, is consistent with slip partitioning, or decoupling of strike-slip and thrust faulting. The slip partitioning model postulates that future moderate-sized or large earthquakes may be caused by rightlateral faulting along northwest striking faults or left-lateral faulting along northeast striking faults. Such faults may segment the major west or west-northwest striking thrust faults. The Northridge Hills fault (Figure 6) is one such strike-slip fault in the epicentral region [Barnhart and Slosson, 1973]. The surficial expression of the fault in the San Fermando Valley is a series of anticlinal hills. Along its westem half, it dips about $80^{\circ}$ to the north, while along the eastem half it is either vertical or dips steeply to the south [Barnhart and Slosson, 1973]. The Northridge Hills fault is thought to be potentially active, and some of the large strike-slip aftershocks may have been associated with it. It offsets both the local groundwater table and the surficial strata, in some cases by a few hundred feet [Barnhart and Slosson, 1973].

The relatively close occurrence of the 1994 Northridge earthquake to the 1971 San Fernando earthquake and spatial association of the aftershock sequences was a surprise. Prior to the 1994 event, segments of the Sierra Madre fault system other than the 1971 San Fernando segment were thought to be more likely to break [Hauksson, 1994b]. In light of rapid tectonic strain accumulation in the region [Donnellan et al., 1993] and the absence of large earthquakes over the last 200 years [Hauksson, 1992], large earthquakes were expected. Although the 1994 and 1971 events occurred on different fault systems, they both released some of the accumulated north-south contractional tectonic strain in the Transverse Ranges. Stein et al. [1994] used dislocation modeling to argue that the 1994 event was triggered by stress loading from the 1971 event. Such a triggering 
mechanism is possible but not required because ample tectonic strain remains stored on faults in the region.

The 1994 earthquake is part of the temporal increase in earthquake activity in the greater Los Angeles area since 1970 (Figure 12). This is the second of two temporal clusters of increased activity recorded since 1900 [Hauksson, 1992]. The first cluster began in 1920 and ended in 1942, and the second began in 1970 and continues to the present. Because the best estimate of the seismicity rate in the near future is assumed to be the current seismicity rate [e.g., Kagan and Jackson, 1994], the high seismicity rate within the current cluster suggests that more damaging earthquakes will occur over the next decade. A continuation of the current seismicity rate will contribute to releasing the contractional tectonic strain that has accumulated in the western Transverse Ranges over a minimum time interval of 200 years.

\section{Conclusions}

There are four main seismological and tectonic lessons from the Northridge earthquake. First, the mainshock hypocenter was relatively deep, suggesting that the seismogenic width of faults in the region may be $5-10 \mathrm{~km}$ greater than previously thought. This large seismogenic width may explain why so many relatively short faults in the region rupture in large earthquakes and thus have prominent surface scarps. Second, the Northridge earthquake and its aftershocks do not correlate easily with any mapped surficial geological faults or folds, although some of the deformation may be controlled by northeast trending lateral ramps. Potential earthquake sources of $M<7$ thus may be routinely missed in geological investigations of the region. Third, the strain released in the 1994 earthquake was not sufficient to significantly decrease the accumulated strain in the region. Because no other major $(M>7)$ earthquakes have occurred in the region for at least 200 years, or possibly longer, significant accumulated strain remains to be released on surficial or concealed faults in the region. Fourth, the relative uniformity of thrust focal mechanisms indicated that the stress release in the mainshock was not complete. Alternatively, slip partitioning plays an important role in the deformation of this region, and future large earthquakes can have a significant strike-slip component.

Acknowledgments. J. Unruh, J. Scott, and D. Wald provided helpful critical reviews. We are grateful to the seismic analysts of Caltech and the USGS for quick and competent processing of the earthquake data. This research was partially supported by USGS grant 1434-94-G-2440, USGS cooperative agreement 1434-92-A-0960, and NSF grant 94-16119 to Caltech. Southern Califormia Earthquake Center publication 125. Contribution 5463, Division of Geological and Planetary Sciences, Califormia Institute of Technology, Pasadena.

\section{References}

Barnhart, J. T., and J. E. Slosson, The Northridge Hills and Associated Faults-A Zone of High Seismic Probability?, in Geology, Seismicity and Environmental Impact, pp. 253-256, Assoc. of Engineering Geologists, Belmont, Calif., 1973.

Beroza, G. C., and M. D. Zoback, Mechanism diversity of the Loma Prieta aftershocks and the mechanics of mainshock-aftershock interaction, Science, 259, 210-213, 1993.

Çemen, I., Near-surface expression of the eastern part of the San Cayetano Fault: A potentially active thrust fault in the Califomia Transverse Ranges, J. Geophys. Res., 94, 9665-9677, 1989.

Davis, T. L., and J. S. Namson, A balanced cross section analysis of the
1994 Northridge earthquake and thrust fault seismic hazards in southern California, Nature, 372, 167-169, 1994.

Dibblee Jr., T. W., Geology of the Santa Monica Mountains and Simi Hills, southern California, in Geology and Mineral Wealth of the California Transverse Ranges, edited by D. L. Fife and J. A. Minch, pp. 94-130, South Coast Geological Society, Santa Ana, Calif., 1982.

Donnellan, A., B. H. Hager, R. W. King, and T. A. Herring, Geodetic measurement of deformation in the Ventura basin region, southern California, J. Geophys. Res., 98, 21,727-21,739, 1993.

Dreger, D. S., Empirical Green's function study of the January 17, 1994 Northridge, California earthquake $\left(M_{w} 6.7\right)$, Geophys. Res. Lett., 21 , 2633-2636, 1994.

Feigl, K. L., et al., Space geodetic measurement of crustal deformation in central and southern California, 1984-1992, J. Geophys. Res., 98, 21,677-21,712, 1993.

Hadley, D., and H. Kanamori, Seismic structure of the Transverse Ranges, Califormia, Bull. Seismol. Soc. Am., 88, 1469-1478, 1977.

Hauksson, E., Earthquakes, faulting and stress in the Los Angeles Basin, J. Geophys. Res., 95, 15,365-15,394, 1990.

Hauksson, E., Seismicity, faults, and earthquake potential in Los Angeles, southem California, in Engineering Geology Practice in Southern California, Belmont, California, edited by B. Pipkin and R. J. Proctor, pp. 167-179, Association of Engineering Geologists, Belmont, Calif., 1992.

Hauksson, E., State of stress from focal mechanisms before and after the 1992 Landers earthquake sequence, Bull. Seismol. Soc. Am, 84, $917-$ 934, 1994a.

Hauksson, E., The 1991 Sierra Madre earthquake sequence in southern Califormia: Seismological and tectonic analysis, Bull. Seismol. Soc. Am., 84, 1058-1074, $1994 \mathrm{~b}$.

Hauksson, E., and L. M. Jones, The 1987 Whittier Narrows earthquake sequence in Los Angeles, southern California: Seismological and tectonic analysis, J. Geophys. Res., 94, 9569-9590, 1989.

Hauksson, E., and G. M. Saldivar, Seismicity and active compressional tectonics in the Santa Monica Bay southern California, J. Geophys. Res., 94, 9591-9606, 1989.

Hauksson, E., et al., The 1987 Whittier Narrows earthquake in the Los Angeles metropolitan area, California, Science, 239, 1409-1412, 1988.

Heaton, T. H., The 1971 San Fernando earthquake: A double event?, Bull. Seismol. Soc. Am., 72, 2037-2062, 1982.

Hudnut, K. W., et al., Coseismic displacements of the 1994 Northridge, Califormia, earthquake, Bull. Seismol. Soc. Am. Special Issue, in press, 1995.

Ishida, M., and H. Kanamori, The foreshock activity of the 1971 San Fernando earthquake, California, Bull. Seismol. Soc. Am., 68, 12651279,1978

Jennings, P., Fault map of California with volcanoes, thermal springs and thermal wells, 1:750,000 scale, geol. data map 1, Calif. Div. Mines and Geol., Sacramento, 1975.

Jones, L. M., Foreshocks (1966-1980) in the San Andreas System, Califomia, Bull. Seismol. Soc. Am.74, 1361-1380, 1984.

Kagan, Y. Y., and D. D. Jackson, Long-term probabilistic forecasting of earthquakes, J. Geophys. Res., 99, 13,685-13,700, 1994.

Kissling, E., W. L. Ellsworth, D. Eberhart-Phillips, and U. Kradolfer, Initial reference models in local earthquake tomography: $J$. Geophys. Res., 99, 19,635-19,646, 1994.

Klein, F. W., User's guide to HYPOINVERSE, a program for VAX and PC350 computers to solve for earthquake locations, U.S. Geol. Surv. Open File Rep., 85-515, 24 pp., 1985.

Mori, J., D. J. Wald, and R. L. Wesson, Overlapping fault planes of the 1971 San Fernando and 1994 Northridge, Califomia earthquakes, Geophys. Res. Lett., in press, 1995.

Namson, J., and T. Davis, Late Cenozoic thrust ramps of Southern California, Final report to the Southem California Earthquake Center, 44 pp., Los Angeles, Calif., 1992.

Proctor, R. J., R. Crook, M. H. McKeown, and R. L. Moresco, Relation of known faults to surface ruptures, 1971 San Fernando earthquake, southem California, Geol. Soc. Am. Bull., 83, 1601-1618, 1972.

Reasenberg, P. A., and L. M. Jones, Earthquake hazard after a mainshock in California, Science, 243, 1173-1176, 1989. 
Reasenberg, P., and D. Oppenheimer, FPFIT, FPPLOT and FPPAGE: Fortran computer programs for calculating and displaying earthquake fault-plane solutions, U.S. Geol. Surv. Open File Rep. 85-739, 109 pp., 1985.

Scientists of the U. S. Geological Survey and the Southern Califomia Earthquake Center, The magnitude 6.7 Northridge, California, earthquake of January 17, 1994, Science, 266, 389-397, 1994.

Stein, R. S., G. C. P. King, and J. Lin, Stress triggering of the $1994 M$ -6.7 Northridge, California, earthquake by its predecessors, Science, 265, 1432-1435, 1994.

Stein, R. S., and R. S. Yeats, Hidden earthquakes, Sci. Am., 260, 48-57, 1989.

Thio, H.-K., and H. Kanamori, Source complexity of the 1994 Northridge earthquake and its relation to aftershock mechanisms, Bull. Seismol. Soc. Am., in press, 1995.

Wald, D. J., and T. H. Heaton, A dislocation model of the 1994 Northridge, Califomia, earthquake determined from strong ground motion, U. S. Geol. Surv. Open File Rep. 24-278, pp. 55, 1994.

Webb, T. H., and H. Kanamori, Earthquake focal mechanisms in the eastern Transverse Ranges and San Emigdio Mountains, southern California and evidence for a regional decollement, Bull. Seismol. Soc. Am., 75, 737-757, 1985.

Wessel, P., and W. H. F. Smith, Free software helps map and display data, Eos Trans. $A G U, 72,441,1991$.

Whitcomb, J. H., C. R. Allen, J. D. Garmany, and J. A. Hileman, San Fernando earthquakes series, 1971: Focal mechanisms and tectonics, Rev. Geophys., 11, 693-730, 1973.
Yeats, R. S., Quaternary flake tectonics of the California Transverse Ranges, Geology, 9, 16-20, 1981.

Yeats, R. S., et al., Oak Ridge fault, Ventrua fold belt, and the Sisar decollement, Ventura basin, California, Geology, I6, 1112-1116. 1988.

Yeats, R. S., Late Quatemary slip rate on the Oak Ridge Fault, Transverse Ranges, California: Implications for seismic risk, J. Geophys. Res., 93, 12,137-12,149, 1988.

Yeats, R. S., Converging more slowly, Nature, 366, 299-301, 1993.

Yeats, R. S., and G. J. Huftile, Oak Ridge fault system and the 1994 Northridge earthquake, Nature, 373, 418-420, 1994.

Yeats, R. S., et al., Oak Ridge fault, Ventura fold belt, and the Sisar decollement, Ventura basin, Califomia, Geology, 16, 1112-1116, 1988.

Ziony, J. I., and R. F. Yerkes, Evaluating earthquake and surface faulting potential, in Evaluating Earthquake Hazards in the Los Angeles Region - An Earth-Science Perspective, ed. by J. I. Ziony, U. S. Geol. Surv. Prof. Pap. 1360, 43-91, 1985.

E. Hauksson and K. Hutton, Seismological Laboratory, Division of Geological and Planetary Sciences, Califomia Institute of Technology, Pasadena, CA 91125. (e-mail: hauksson@seismo.gps.caltech.edu) L. M. Jones, U.S. Geological Survey, Pasadena, CA 91106.

(Received November 15, 1994; revised March 3, 1995; accepted March 13, 1995.) 